\title{
APROXIMACIÓN A LA CULTURA MATERIAL ASOCIADA AL CULTO DOMÉSTICO EN EL MUNDO ROMANO
}

\author{
Surveying the material culture related to the domestic cult \\ in the Roman world
}

\author{
María Pérez Ruiz ${ }^{1}$ \\ Recibido el 2 de agosto de 2012. Aceptado el 20 de septiembre de 2012
}

Resumen. Imágenes de culto, árulas, lucernas y muchos otros tipos de objetos formaban parte de los ajuares que se utilizaban en los lararios para el desarrollo de los ritos domésticos en época romana. En este trabajo se realiza un análisis de estos materiales, tanto en el conjunto del mundo romano -con la referencia principal de las ciudades vesubianas-, como de forma más específica en las provincias Baetica yTarraconensis. Se valoran, asimismo, la importancia de estos materiales para el mejor conocimiento del culto doméstico en época romana y los problemas que se presentan para su identificación.

Palabras clave: imagen de culto, objeto ritual, instrumentum domesticum, larario, religión privada, época romana, Pompeya, Hispania.

Abstract. Cult images, portable altars, oil lamps and many other types of objects were part of the house furnishings used in lararia for the celebration of the domestic rites in the Roman period. An analysis of this material culture is carried out in this paper, in the Roman world as a whole - with the main reference of the Vesuvian cities-, and more specifically in the Roman provinces Baetica and Tarraconensis. The importance of these archaeological evidences for a better knowledge of the Roman domestic cult, as well as the problems for their correct identification in relation to the cult, are discussed.

Key words: cult image, ritual object, instrumentum domesticum, lararium, private religion, Roman period, Pompeii, Roman Spain.

\section{MATERIALES ASOCIADOS A ESPACIOS PARA EL CULTO DOMÉSTICO EN EL MUNDO ROMANO $^{2}$}

Los tipos de objetos hallados en contextos de culto doméstico en época romana son muy variados, pudiendo hallarse desde los que podrian considerarse más típicos 0 directamente asociados al ritual doméstico, como las árulas e imágenes de divinidades, hasta instrumentum domesticum, cuya relación no resulta tan clara (Bassani 2008: 125).
George Boyce, en su catálogo de los lararios pompeyanos, agrupaba ya este conjunto heterogéneo de materiales según los dos componentes propios de los espacios de religiosidad doméstica: la representación de las imágenes veneradas y la presencia de objetos para el desarrollo del culto ante dichas imágenes (Boyce 1937: 10). La representatividad de estos materiales como objetos de culto y la facilidad para reconocerlos como tales varía de unos a otros, como se irá viendo en la tipificación y el análisis los testimonios con los que contamos.

(') Dpto. de Prehistoria y Arqueología, Facultad de Filosofia y Letras, Universidad Autónoma de Madrid. Carretera de Colmenar km. 15, 28049, Madrid.mariaperezruiz@yahoo.es.

${ }^{(2)}$ En este apartado nos basaremos principalmente en la documentación procedente de las ciudades vesubianas, por ser la más abundante y la mejor conocida, si bien haremos también referencia a casos fuera de esta zona. 


\subsection{Imágenes de culto}

Las esculturas son seguramente el conjunto más abultado de materiales hallados en lararios. En su gran mayoría son de pequeño tamaño, normalmente no superiores a los $30 \mathrm{~cm}$ y un gran número incluso inferiores a los $15 \mathrm{~cm}^{3}$. Pero existen también ejemplos de mayores dimensiones, entre los que destaca una estatua femenina en mármol, capite ve$l a t{ }^{4}$, que supera el tamaño natural con $185 \mathrm{~cm}$ de altura y que ha sido hallada en la Villa dei Misteri (Pompeya), asociada a una gran estancia dedicada al culto ${ }^{5}$ (Bassani 2008: 125-127, 200-201).

El material más utilizado y predominante en las esculturas conservadas es el bronce, con mucha menor presencia de la terracota ${ }^{6}$ y del mármol, que parece además reservado para las estatuas de gran formato. Así lo demuestra el estudio realizado por Annemarie Kaufmann-Heinimann (2007a: 155) para las esculturas de divinidades halladas en espacios de culto doméstico pompeyanos, y los testimonios hallados en otras zonas de mundo romano parecen confirmar esta predominancia del bronce ${ }^{7}$. Las fuentes escritas dan cuenta también del uso de otros materiales: metales preciosos como la plata (Petron. 29, 8; Amm. XXII, 13, 3) o el oro (Suet., Aug. 2, 5; Plut., Sull. XXIX,6), de los cuales se conservan algunos testimonios arqueológicos ${ }^{8}$, o materiales modestos como la cera (luv., 12, 87-89) y la madera ${ }^{9}$ (Tibull., I, 10, 10-15). Se usaron también el alabastro, el marfil y el ámbar, aunque están escasamente documentados ${ }^{10}$ (Kaufmann-Heinimann 1998: 185; 2007: 155).

La relativa abundancia de esculturas en bronce de pequeño formato en contextos de larario ${ }^{11}$ (Figura 1) ha hecho que su hallazgo en estructuras domésticas permita suponer, casi de forma inmediata, la existencia de una actividad ritual religiosa, aunque no haya un espacio definido para el culto; no en vano, es frecuente encontrar referencias a ellas en la bibliografía como "esculturas de larario".

No resulta igual de sencillo identificar esculturas en piedra con valor cultual, a pesar de que representen divinidades, pues otros usos domésticos como el ornamental están también ampliamente atestiguados, a lo que se suma la inexistencia de un patrón de tamaño, como ocurre con los bronces, o incluso de tema iconográfico que permita discernir su uso cultual cuando no proceden de lararios ${ }^{12}$. Wilhelmina Jashemski (1979: 121) considera, sin embargo, que la distinción entre objeto de arte y de culto es más una construcción moderna que una percepción de los propios antiguos ${ }^{13}$, de forma que, por ejemplo, la presencia de estatuas de divinidades en jardines es una indicación evidente de una actividad ritual ${ }^{14}$.

Por lo que respecta a las esculturas de terracota (Figura 2), ya A. Kaufmann-Heinimann (1998: 159) ha señalado que es difícil saber si su escasa presencia en el registro

(3) Asi parece desprenderse a partir de la observación de las dimensiones de las esculturas de bronce recogidas por A. Kaufmann-Heinimann (1998) en su estudio sobre los lararios de Augusta Raurica (Augst, Suiza). S. Boucher y H. Oggiano-Bitar (1995: 233) afirman, por su parte, que la media de los pequeños bronces de larario es inferior a los $12 \mathrm{~cm}$.

(4) La escultura ha sido interpretada tradicionalmente como una representación de Livia, si bien A. Varone considera que se trata de una sacerdotisa de la familia de los Istacidii, los últimos dueños de la villa (Varone 2002: 347).

(5) Otros ejemplos significativos son la escultura en mármol de Diana arcaizante hallada en la casa pompeyana de M. Spurius Saturninus (VII, 6 , 3), de $116 \mathrm{~cm}$ de alto (Bassani 2008: 127, 226-227); o la imagen también en mármol de Isis que presidia el larario de la casa bajo la Iglesia de San Martino ai Monti, en Roma, de $146 \mathrm{~cm}$ (Guglielmi 2007a, con bibliografia).

(6) Véase, especialmente, el conjunto de esculturas del larario en el jardín de la casa IX, 7, ?, de Pompeya (Boyce 1937, 89, n. 446; AdamoMuscettola 1984, 10; Figura 2).

(7) Véase la recopilación de esculturas en bronce halladas en contextos cerrados de lararios realizada por A. Kaufmann-Heinimann (1998: 209-318).

(8) El ejemplo más sobresaliente de imágenes de culto en plata es el que forma parte del conocido como "Trésor de Mâcon", interpretado como probablemente procedente de un larario (Kaufmann-Heinimann 2007b). También en plata están realizadas las esculturillas halladas en el larario de la villa de Scafati, en el agro vesubiano (ibid.: 30), y la estatuilla de Harpócrates de la Casa di M. Memmius Auctus, en Pompeya (VI, 14, 27; Kaufmann-Heinimann 1998: 219, GFV26).

(9) Probablemente de madera fue la imagen de Mercurio hallada en el gran nicho de una de las exedras del peristilo de la Casa del Menandro, en Pompeya (I, 10, 4; Allison 2006: 85). De ella y de los bustos que la acompañaban, también seguramente lígneos e interpretados como la representación de los antepasados familiares venerados en la casa (Maiuri 1932: 98-106), queda solo el vaciado en yeso (Figura 3). En la Casa a Graticcio de Herculano $(I I, 13,15)$ si se ha conservado un busto femenino en madera junto con un larario del mismo material (Charles-Laforge 2007: 160); el busto fue comparado por Maiuri (1932: 102) con los hallados en la Casa del Menandro y su interpretación debe ser también la misma.

(10) Se ha hallado una Venus de marfil en la Casa degli Epigrammi, en Pompeya (V, 1, 18.11-12; Kaufmann-Heinimann 1998: 217, GFV20). En la misma ciudad, del larario de la casa V, 4,9 proceden otra escultura de Venus de alabastro y una escultura masculina de marfil (ibíd.:219, GFV24).

(11) Aunque este es el tipo de estatuas hallado con más frecuencia en lararios, el número de ellas o de conjuntos de ellas procedentes con seguridad de estos espacios en Pompeya es de treinta, una cifra no muy elevada frente a las más de 800 casas documentadas en la ciudad (Kaufmann-Heinimann 2007a: 151). Su colocación en otros lugares de la casa tras el terremoto de 62 d.C., mientras se reparaba la capilla doméstica, o el hecho de que los habitantes de la ciudad se las llevaran consigo en su huída de la erupción del Vesubio, son posibles razones para este número no muy alto de hallazgos in situ (Adamo Muscettola 1984: 9). Para algunas esculturas en bronce halladas en las calles, véase Boyce 1937: 108-109.

(12) Se puede obtener una idea de esta diversidad de las esculturas en piedra con valor cultural observando las halladas en los sacraria pompeyanos (Bassani 2008: 127).

$\left({ }^{13}\right)$ En la misma línea se expresa A. De Marchi (1896: 94), poniendo como ejemplos ilustrativos la estatua de Cupido realizada por Praxiteles y venerada en el sacrarium de Heius en Mesina, según cuenta Cicerón (Verr. 2, IV, 3-7), y la de Hércules de Lisipo venerada por Novius Vindix, según Estacio (silv. IV, 6). Véase también Santrot 2007: 89-91.

(14) Sobre la relación de la religión doméstica con los espacios ajardinados, véase especialmente Jashemski 1979 y, en relación con Diana, Bassani 2008: 128-132. 


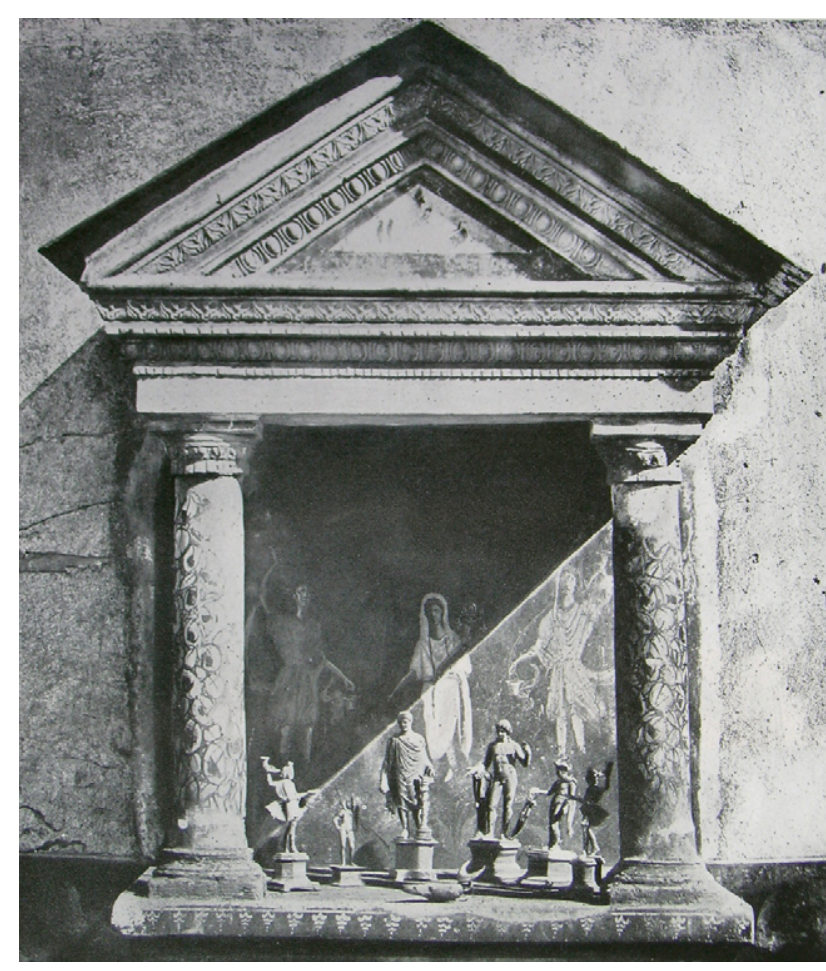

A Figura 1. Edículo de la Casa delle Pareti Rosse (Pompeya), con las "esculturas de larario" y la lucerna en bronce que se hallaron en él. Boyce 1937: lám. 31.1.

material se debe al mayor interés de la investigación actual por otros materiales, como las esculturas de bronce, con el consiguiente descuido de estos hallazgos en las excavaciones y olvido en las publicaciones, o si se trata del reflejo de la realidad antigua. La lectura en clave económica del uso de materiales como la terracota o la madera frente al bronce 0 la piedra debe quedar también en suspenso por el momento, ante la falta de documentación suficiente para abordar la cuestión, a lo que en el caso de la madera hay que sumar su casi total desaparición del registro material, con la excepción de algunos testimonios vesubianos ${ }^{15}$ (Figura 3).

Las imágenes de culto solían colocarse dentro de nichos o en edículos, en el caso de las de menor tamaño, y en hornacinas en la pared o sobre podios en estancias dedicadas al culto, en el caso de las más grandes (Figura 1). Precisa-
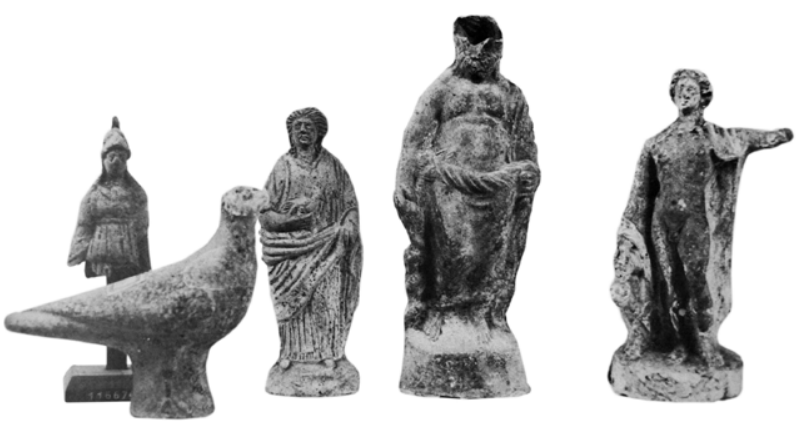

A Figura 2. Imágenes de culto en terracota del larario de la casa IX, 7, ?, Pompeya. Adamo-Muscettola 1984: 10, fig. 2.

mente por estar asociadas a los lararios más monumentales, solian encontrarse en las zonas públicas y de representación de la casa (atrios, peristilos, etc.), aunque no solo, pues en Pompeya y Herculano se han hallado esculturas en bronce también en cubicula ${ }^{16}$, si bien suelen presentar una calidad menor que las halladas en las zonas públicas de la casa (Adamo-Muscettola 1984: 25).

En cuanto a las imágenes representadas, se trata de las divinidades domésticas y de otras del panteón romano en su gran mayoría, aunque también están presentes divinidades con otro origen, como las orientales ${ }^{17}$. Predominan los Lares $y$, en segundo lugar, Mercurio, seguido por Minerva, Venus, Júpiter y Fortuna y, en menor medida, por el Genius, Hércules, Apolo, Harpócrates, Victoria y Eros ${ }^{18}$. Pero también muchas otras figuras tenian cabida en los lararios: imágenes de antepasados, como las de la Casa del Menandro en Pompeya ${ }^{19}$ (vid.n. 9); bustos de emperadores, filósofos, oradores, místicos... (Suet., Aug. 7, 1; Vit. 2, 5; Ov., Pont. II, 8, 1-6; Hist. Aug. Alex. Sev. 29, 2, 31, 4); hermae ${ }^{20}$, y animales como serpientes, toros, perros, gallos, leones, etc. ${ }^{21}$.

Las composiciones, como ocurre también en las pinturas, $^{22}$ son múltiples, de manera que no hay un grupo prioritario de divinidades presentes en los lararios; las repeticiones son raras, con la excepción de los Lares, que aparecen normalmente pareados. Kaufmann-Heinimann (2007a: 153) subraya que los conjuntos de estatuillas pompeyanos son muy heterogéneos, sin que exista necesariamente unidad en los mate-

(15) Véase nota 10

(16) Son los dei csubiculares referidos por Suetonio (Aug. 7, 1; Dom. 17, 2) y hallados, por ejemplo, en la Casa a Gratticio de Herculano (III, 14 , 13, 15) (Adamo-Muscettola 1984: 25-26).

$\left.{ }^{17}\right)$ No existían restricciones en cuanto a los dioses a los que se podia rendir culto en la casa, a diferencia del ámbito público, por lo que incluso algunos entraron en el panteón romano primero por esta vía (De Marchi 1896: 28).

${ }^{(18)}$ Datos de los contextos cerrados de lararios con escultura en bronce en el conjunto del mundo romano, tomados del trabajo de A. KaufmannHeinimann (1998: 193, fig. 138).

$\left.{ }^{19}\right)$ Las imagines maiorum no deben, en cambio, considerarse imágenes de culto, como han expresado H. Flower (1996: 2-3, 10) y F. Bömer (1943: 115-117).

${ }^{(20}$ S Sin embargo, los hermae no se documentan frecuentemente en los lararios. G. Boyce (1937) no da referencias de este tipo de hallazgos en su catálogo y M. Bassani (2008: 126, tabla 12) recoge sólo dos sacraria pompeyanos en los que hayan aparecido. Fuera de la región vesubiana, se han documentado tres en el sacellum de San Martino ai Monti, en Roma (Guglielmi 2007b), y otro en la Casa de la C/ Boukaouri de Patrás (Bonini 2011: 208).

(21) Kaufmann-Heinimann 1998: 215, GFV9; 226, GFV47; 224, GFV43; 229, GF4; 237, GF16, respectivamente.

(22) Para las pinturas asociadas a lararios, el trabajo de referencia sigue siendo el de Fröhlich 1991. 


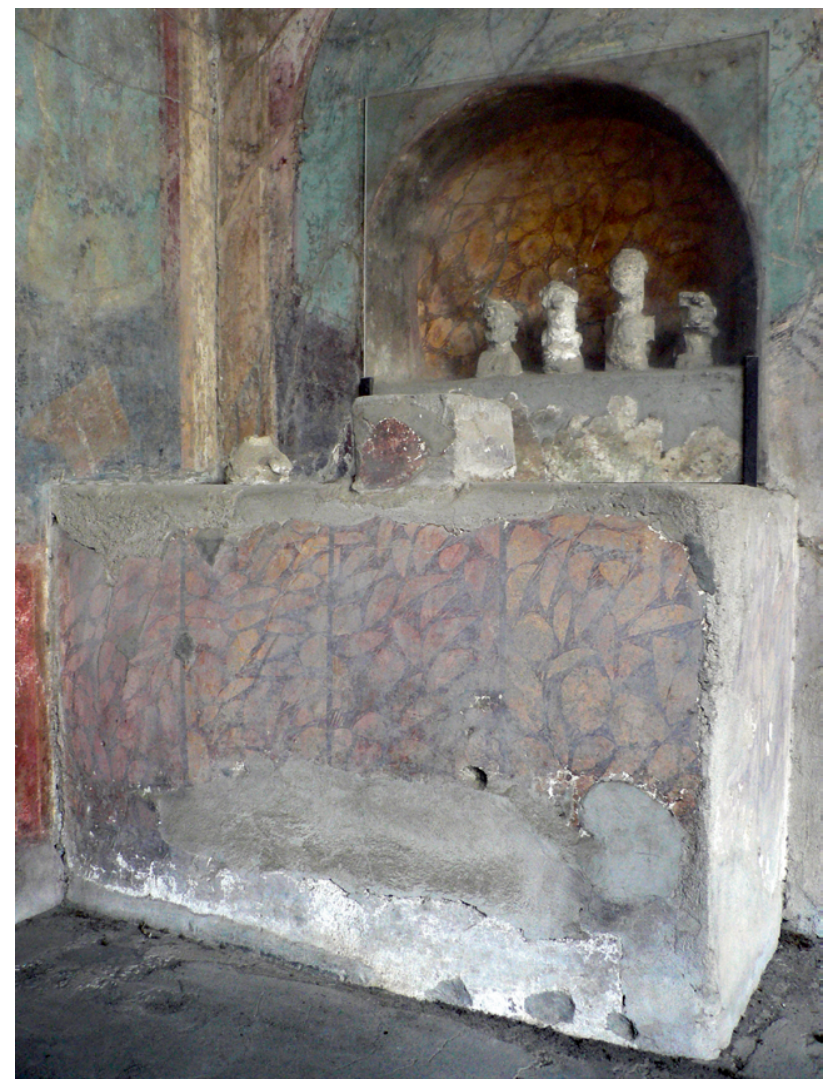

$\Delta$ Figura 3. Larario en el peristilo de la Casa del Menandro (Pompeya). En el nicho, vaciados en yeso de bustos esquemáticos originalmente en madera, representación de los antepasados familiares. Junto a ellos se documentó una escultura de Mercurio en el mismo material, hoy perdida. M. Pérez Ruiz.

riales, la talla o la calidad, lo cual parece demostrar que en muchos casos se formaron en un largo período de tiempo, respondiendo a las preferencias de sucesivos miembros de la familia ${ }^{23}$.

También en otras zonas del mundo romano se han documentado, en un mismo larario, esculturas con diferentes dataciones -la mayoría de los ss. I-II d. C.- y procedencias -piezas locales junto a importaciones- que se mantienen en uso durante un largo período de tiempo (KaufmannHeinimann 1998: 192; Adamo-Muscettola 1984: 11-12; Stirling 2008). Según A. Kaufmann-Heinimann (1998: 192), la mayoría de los contextos de lararios con esculturas en bronce se amortizan en el s. III d.C., como ocurre en la Villa de Vilauba (Camós, Gerona), donde las esculturas de larario se han fechado estilísticamente en el s. I d.C., por lo que estuvieron en uso dos siglos (vid. inf.). En este y otros casos la datación estratigráfica del contexto no coincide con el momento de elaboración de las esculturas. Para conocer este

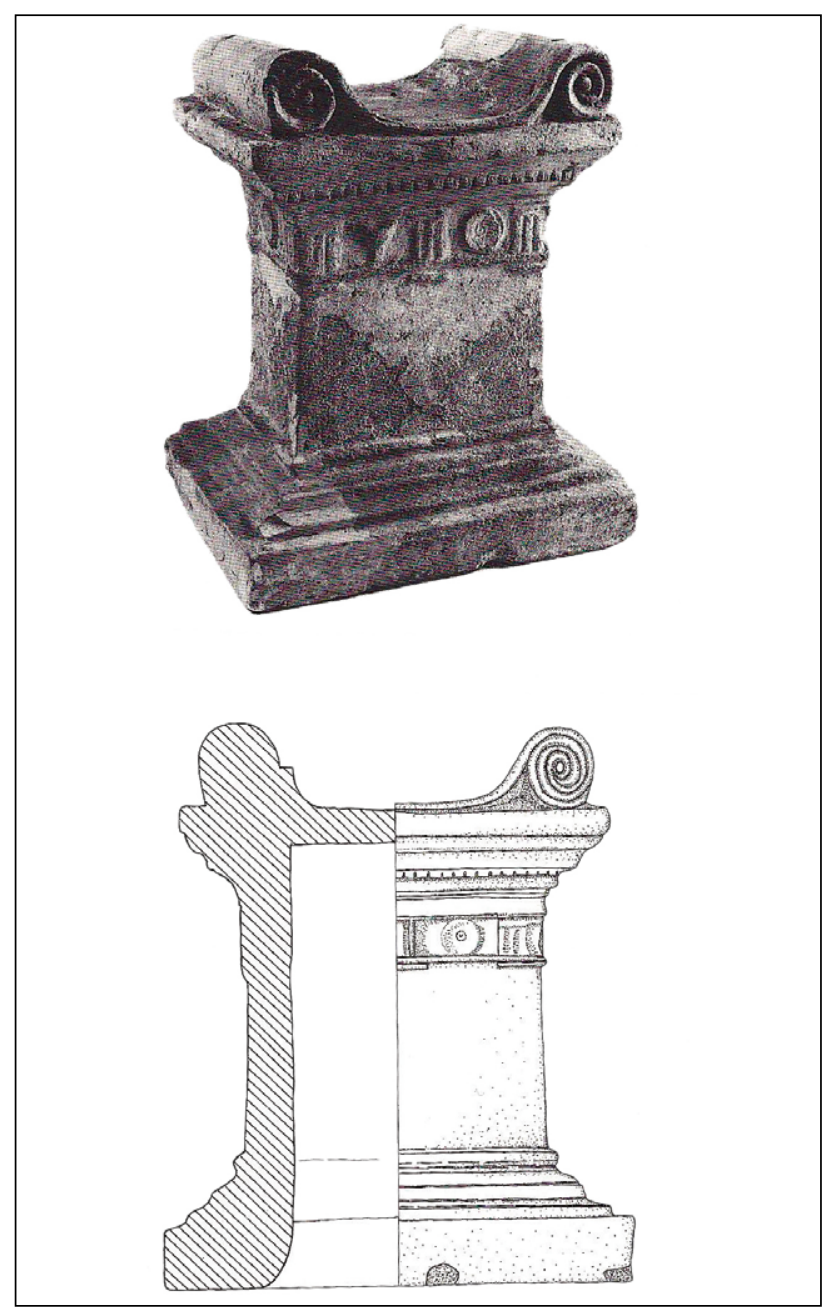

$\Delta$ Figura 4. Árula de terracota de la Casa di L. Helvius Severus, Pompeya. d'Ambrosio y Borriello 2001: 30, n. 25.

último y, por tanto, el período que estuvo en uso una escultura es necesario analizar cada caso individualmente, como han demostrado Stéphanie Boucher y Hélène Oggiano-Bitar (1995: 236) para las estatuillas de bronce de Lares, en las que el contexto, el estilo, la calidad, la comparación y la evolución estilística se han mostrado insuficientes como criterios absolutos de datación, dando en ocasiones importantes márgenes de error.

\subsection{Objetos rituales}

Una valoración de los objetos rituales debe comenzar necesariamente por las aras y las árulas, pues, si bien posiblemente el tipo de pieza que más directamente se suele asociar al culto doméstico romano son las esculturas en bronce de pequeño formato de las que acabamos de hablar,

${ }^{(23)}$ Véase como ejemplo el conjunto de esculturas halladas en dos armarios asociados al larario de la Casa di un Flamine $\left(V_{1}, 4,3\right), 0$ el procedente del larario en el corredor que comunicaba con el jardin en la Casa del Cenacolo (V, 2, h). En ambos casos, las esculturas están realizadas con diferentes materiales, calidades y tamaños (Kaufmann-Heinimann 2007a: 153-154 con bibliografia). Otros casos en Kaufmann-Heinimann 1998: 185. 


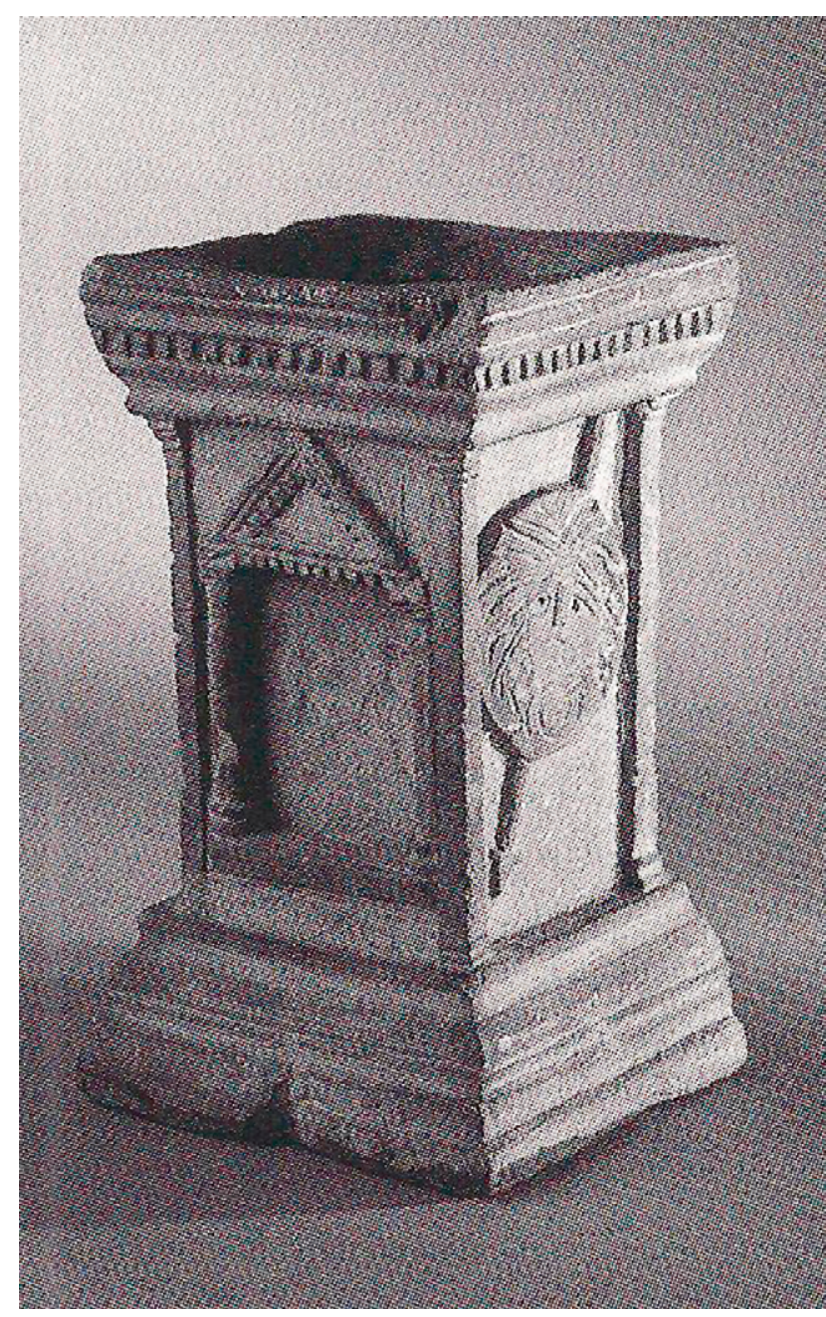

A Figura 5. Árula de tufo procedente de una taberna con zona de habitación en Herculano. Guidobaldi 2003: 109.

las aras y árulas ${ }^{24}$ son los materiales que indican de forma más inequívoca el desarrollo de una actividad religiosa en la casa, pues el ara es "Le dispositif destiné à permettre le rite du sacrifice à une divinité" (Ginouvés 1998: 48) y tiene, por tanto, un valor religioso intrínseco. Sin embargo, su presencia y su función doméstica ritual han sido objeto de menor interés por parte de los investigadores que las esculturas.

George Boyce (1937: 16) hace una breve valoración de las árulas domésticas pompeyanas y subraya que eran mucho más comunes que los altares realizados en mampostería. Aunque habla de que se ha hallado un gran número de ellas ${ }^{25}$, no es posible dar una cifra exacta, si bien Antonio d'Ambrosio y Mariarosaria Borriello $(2001: 15,24)$ contabilizan 30 pétreas y 19 de terracota. Pocas de estas árulas han sido halladas en lararios, pero en el caso de las de terracota d'Ambrosio y Borriello consideran que, a pesar de que de muchas se desconoce la procedencia exacta y ninguna está asociada directamente a un larario (ibid.: 91-92), deben interpretarse de forma genérica como objetos rituales domésticos, dado que buena parte procede de casas (ibíd:: 17; Figura 4).

Los materiales usados para su realización fueron la piedra -tufo, mármol, travertino y arenisca-, la terracota y el bronce, con una enorme variedad de formas, tamaños, tipos y decoraciones: existen árulas de bronce con incrustaciones de plata; de mármol decoradas con objetos de culto (páteras, guirnaldas...); de tufo con forma cilindrica y revestimiento de estuco (Figura 5), etc. (Boyce 1937: 16).

Según Francesco Di Capua (1950: 84), las árulas halladas en Pompeya no se prestaban a la realización de sacrificios cruentos, sino que estaban destinadas a libaciones y a la quema de incienso, cuyo uso se difundió en época helenística e imperial en la creencia de que agradaba a las divinidades benéficas y alejaba a las maléficas. En algo más de un tercio de las árulas en terracota se han hallado huellas de combustión en la superficie de uso ${ }^{26}$ (d'Ambrosio y Borriello 2001: 17), lo cual recuerda también el importante papel del fuego, elemento central y primordial del culto doméstico romano (De Marchi 1896, 102-103; Pérez Ruiz 2011a: 207-208). Darma Ricciotti (1978: 14) añade a estos usos de las árulas el de recibir las ofrendas para los dioses o espíritus, como aparece ilustrado en muchos lararios pictóricos en los que sobre los altares hay piñas y huevos, que se ofrecen en muchos casos a las serpientes ${ }^{27}$ (Pérez Ruiz 2011b: B95; Figura 7); incluso se han documentado restos de estas ofrendas en Pompeya ${ }^{28}$.

G. Boyce (1937) no hace referencia en su catálogo a ningún árula con inscripción en casas pompeyanas ${ }^{29}$, mientras que sí se refiere a epígrafes asociados al culto domés-

${ }^{24}$ La diferencia entre ambas está en el tamaño, que hemos establecido en hasta $30 \mathrm{~cm}$ para las arulae y a partir de $30 \mathrm{~cm}$ para las aras.

(25) Boyce hace alusión a docenas de ellas que se encontraban en el almacén junto a la esquina NO del Foro de la ciudad (Boyce 1937: 16), pero que parecen ser las mismas que, según 0. Elia (1962: 561, n. 1), se perdieron en su mayoría como resultado de los bombardeos sobre Pompeya durante la II Guerra Mundial.

(26) En la Casa de Obellius Firmus, en Pompeya (IX, 14, 3-4), se da noticia del hallazgo de un contenedor de hierro para carbón en relación con un árula o, según la tipología de d'Ambrosio y Borriello (2001), más bien un quemaperfumes (Boyce 1937: 31, n. ${ }^{\circ}$ 67).

${ }^{(27)}$ Los casos son múltiples. Véanse como ejemplo, además de la Figura 7 aquí, la pintura en el interior del larario tipo nicho en el atrio de la Casa degli Scienziati (Pompeya, VI, 14, 43), en la que se representa a una serpiente enroscada a un altar con un huevo encima; o el larario pictórico con nicho en la cocina de la Casa di Balbo (Pompeya, I, 8, 18), con dos serpientes que se acercan a un altar con ofrendas de piña y huevos. Ambos en Fröhlich 1991: 254, L10; 279, L69.

${ }^{(28)}$ En el sacrarium subterráneo de la Casa di N. Popidius Priscus (VII, 2, 20.40) se hallaron una piña y cuatro piñones carbonizados sobre un altar circular de mampostería (Bassani 2008: 133, 185).

$\left.{ }^{29}\right)$ Si se han documentado inscripciones, en cambio, en dos altares fijos hallados en el jardín de la Villa di N. Popidius Florus (Boscoreale), con el nombre del dueño de la villa y de las divinidades veneradas (Bassani 2008: 29). 


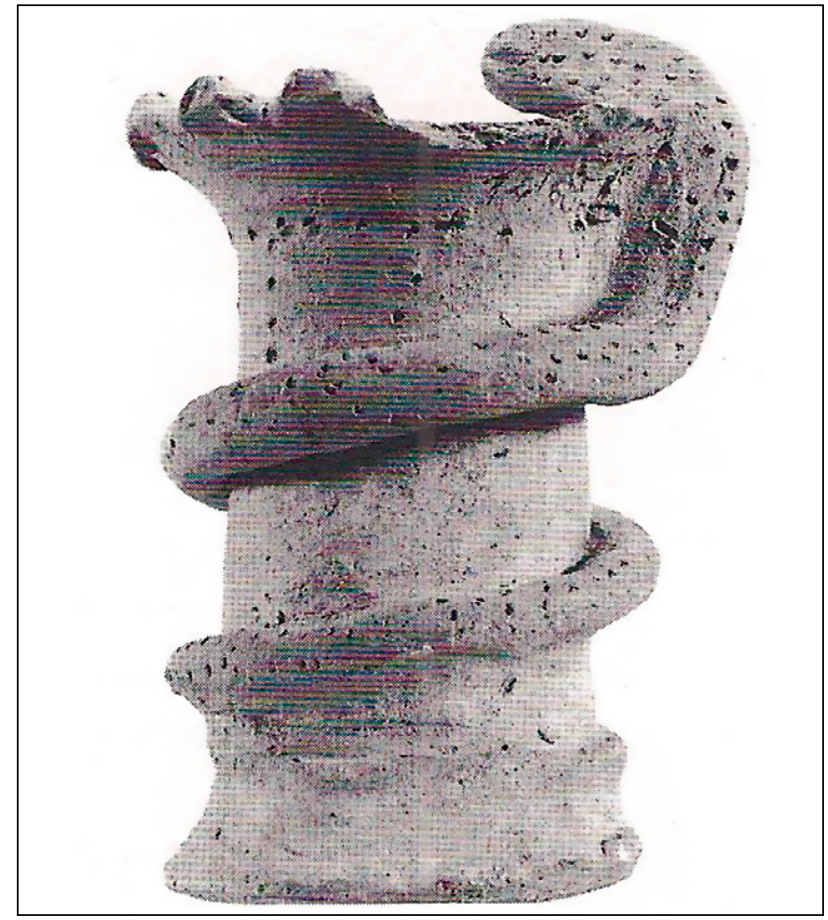

A Figura 6. Quemaperfumes con decoración plástica de serpiente. Hallado en un larario tipo nicho en el corredor de acceso al jardín en la Casa del Cenacolo, Pompeya. d'Ambrosio y Borriello 2001: 42, n. ${ }^{\circ} 47$.

tico en otros soportes ${ }^{30}$. Los casos de árulas domésticas con epigrafía procedentes de la región vesubiana son, de hecho, escasos $^{31}$; fuera de esta región, conocemos algún ejemplo más -además de los hispanos, que trataremos más adelante-, como el árula dedicada a Zeus Katabates hallada en una casa de Cos (Grecia) junto con esculturas de Dioniso y Afrodita y restos de una pila lustral (Bonini 2011: 213).

También otros objetos rituales hallados en las casas pompeyanas cumplian la función del ara, como los tripo$\operatorname{des}^{32}$ y los quemaperfumes o thymiateria, que, al igual que los altares, aparecen representados también en las pinturas litúrgicas (Bassani 2008: 28; De Marchi 1896: 104).

Los thymiateria o quemaperfumes de terracota hallados en Pompeya han sido estudiados por A. d'Ambrosio y M. Borriello ${ }^{33}$ (2001). Para estos autores resulta llamativo que el número de los procedentes de contextos domésticos no sea muy alto, como si no hubiesen tenido una gran difusión, lo cual se explicaría por su aparente uso principalmente en casas señoriales, especialmente en las más grandes y ricas (ibíd:: 15). En los pocos casos en los que se conoce el lugar exacto de su hallazgo se trata de lararios, lo cual demuestra la estrecha relación que tenían con el culto doméstico (ibid.: 17, 91-97). Las huellas de fuego en la superficie de uso de muchos de ellos muestran que se usaron principalmente para quemar ofrendas, así como para contenerlas ${ }^{34}$.

Estos objetos tienen formas heterogéneas: cuenco, copa, cáliz, de pie alto, con forma cilíndrica (Figura 6) y con forma de cuna (un tipo peculiar pompeyano). Son más numerosos que las árulas realizadas también en terracota y destacan los tipos locales (ibid.: 15), que son además especialmente interesantes. Los que tienen forma de cuenco y apliques figurados podrian identificarse como las sigillatae patellae de las fuentes ${ }^{35}$, recipientes en los que se aplicaban imágenes de divinidades y que eran utilizados para realizar las ofrendas de comida a los dioses domésticos (ibid:: 17-18). Los que tienen forma de cuna debieron de estar relacionados, por la forma y la iconografía de los apliques, con ritos dedicados a los niños, como el dies natalis, el dies lustricus o la sollemnitas togae purae (ibíd:: 18). Por su parte, los de pie alto -los estrictamente denominados thymiateria por d'Ambrosio y Borriello- son de origen griego $y$, dado que suelen hallarse en contextos funerarios y en santuarios quizá en relación con cultos ctónicos (ibíd:: 19), es posible que su presencia en la casa deba vincularse también a la dimensión funeraria del culto doméstico.

También las mensae tienen relación con los altares para algunos autores, pues según ellos cumplian la misma función ritual, con la diferencia de que sobre las primeras se colocaban los huevos, los frutos, etc., y sobre los segundos se llevaban a cabo los sacrificios cruentos. Para otros autores, en cambio, si bien la mesa podía recibir ciertos tipos de ofrendas, en ella no se desarrollaba el sacrificio propiamente dicho como en el altar (Bassani 2008: 28-29 con bibliografía). En cualquier caso, no es un elemento frecuente en los lararios ${ }^{36}$, pero es un mueble de destacado valor sacro (Deonna y Re-

(30) Véase el indice analítico del catálogo de Boyce, s.v. "Inscriptions" (Boyce 1937: 102).

(31) Una de las árulas con inscripción más interesantes es la hallada en la Casa del Fauno (VI, 12, 1-8), en Pompeya, con el texto osco Fluusai (Pernice 1932: 66). En una taberna con zona de habitación de Herculano (Ins. Or. II, 10) se halló un árula de tufo con decoración en relieve y la inscripción Hercules, ya casi perdida (Guidobaldi 2003: 109-110, I.30; Figura 5).

(32) Del sacrarium de la Proedria di lulia Felix, en Pompeya (II, 4, 1-12), procede un tripode de bronce con un brasero encima (Bassani 2008: 132).

(33) Estos autores diferencian formalmente en su catálogo entre thymiateria y quemaperfumes.

(34) Algunos quemaperfumes y árulas pompeyanos presentan pequeños orificios que pudieron servir para colocar flores y elementos vegetales, como también se hacía en Grecia para adornar los altares (d'Ambrosio y Borriello 2001: 17). De forma similar, se ha propuesto que los llamados "pebeteros" con forma de cabeza femenina hallados en múltiples asentamientos ibéricos, asociados en algunos contextos también con cultos domésticos, hubieran servido para contener espigas u otros elementos vegetales a modo de ofrendas, dado que en muchos casos no presentan huellas de fuego (Ruiz de Arbulo 1994: 159).

${ }^{35}$ S Sobre las patellae se hablará más adelante en este mismo apartado.

(36) G. Boyce da noticia de solo tres mesas relacionadas con lararios en Pompeya: en un thermopolium delante de un nicho (Boyce 1937: 30 , n. ${ }^{\circ}$ 1), en la casa $\mathrm{VI}, 16,36$ delante de un edículo (ibid.: 59, n. $\left.{ }^{\circ} 229\right)$ y en la Casa del Vinaio (IX, 9, 6-7.10), junto al vano de acceso al sacrarium (ibid: 91, n. ${ }^{4} 59$ ) 


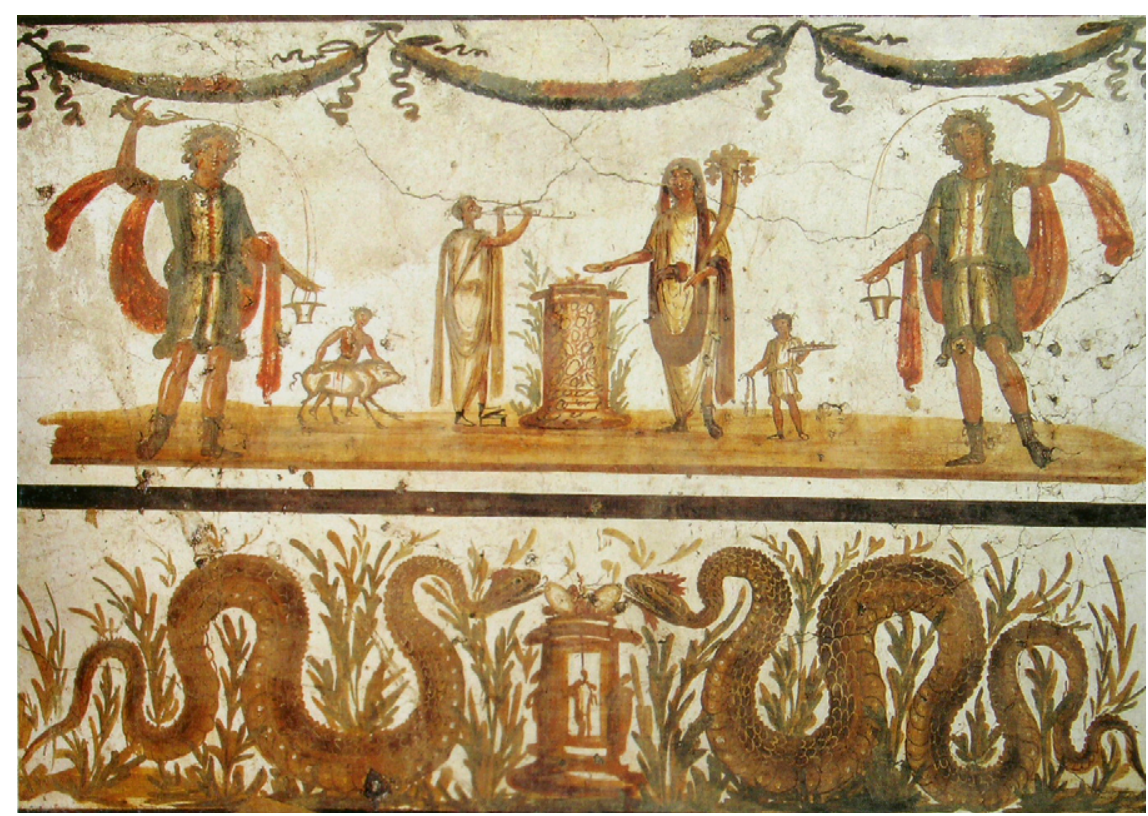

4 Figura 7. Larario pictórico procedente de una casa en la insula VII u VIII de Pompeya. Fröhlich 1991: lám. 10.2, L98. nard 1961: 46-50), relacionado con épocas arcaicas en las que, según las fuentes escritas, en él se colocaba a los dioses para que participasen de las comidas familiares (Prop., III, 7, 45; Ov., fast. VI, 305-306; Tibull., I, 1, 37-38). Plutarco (qu. $R$. 64) recuerda además que la mesa de los romanos, como objeto sagrado, no podía quedarse completamente vacía (De Marchi 1896: 98-100). Pero esta sacralización de la mesa más que perpetuarse en relación con el larario, parece haberlo hecho en el cartibulum colocado en el atrio.

Otros tipos de objetos rituales que se han documentado frecuentemente en los lararios son las lucernas y los candelabros ${ }^{37}$. En Pompeya, algunas lucernas se han encontrado aún in situ dentro de nichos o edículos (Figura 1), normalmente realizadas en terracota, pero en ocasiones también en bronce ${ }^{38}$, pudiendo hallarse más de una en un mismo larario ${ }^{39}$. Además de dar luz, en el larario las lucernas debian de tener el mismo valor ritual que se les otorgaba en otros contextos religiosos ${ }^{40}$. Su luz podía ser un complemento de las ofrendas de incienso en el altar (Ruiz de Arbulo 1996: 119) o estar en relación con los cultos mistéricos (Bassani 2008: 133) con los que parecen estar conectados algunos lararios vesubianos (Di Capua 1950: 81-82). Precisamente, un árula de terracota hallada en la Villa de Vilauba (Camós, Gerona) y decorada con la procesión triunfal de Cibeles y Attis presenta dos lucernas adosadas en los costados, relacionadas con el uso ritual de luz en algunos cultos mistéricos de marcado carácter fúnebre (Ruiz de Arbulo 1996, 120-121; vid. inf.). Cabe también suponer que su llama simbolizase el fuego que debía mantenerse encendido permanentemente en la casa.

A pesar de que es frecuente encontrar motivos religiosos decorando los discos de las lucernas romanas, esto no las conecta necesariamente con los espacios de culto, ni era tampoco un tipo de decoración requerida para las que tuvieran un uso ritual. En la Casa de Attalos Paterklianos, en Pérgamo, ninguna de las seis lucernas halladas en la capilla doméstica tenía decoración alusiva a divinidades o actividades cultuales (Kaufmann-Heinimann 2011: 196).

No puede dejar de mencionarse entre los objetos rituales domésticos la pátera (patella), considerada por algunos autores "l'instrument religieux par excellence" (Pottier en Daremberg-Saglio IV, s.v. "Patella", 341). La pátera, que se ve en las pinturas y en las esculturas en manos de los Lares, el Genius (Figura 7) o Vesta, era el plato en el que se presentaban las ofrendas de comida a los dioses, o bien con el que se inmolaban en el fuego (De Marchi 1896: 101). Una de pequeñas dimensiones ha sido hallada el sacrarium de la Villa Fondo d'Acunzo (Bassani 2008: 126, tabla 12; 212-213, n. ${ }^{\circ} 26$ ).

Junto con la patella nos parece adecuado considerar como objeto ritual doméstico el salinum. La sal era un ali-

${ }^{(37)}$ Dos candelabros de bronce y uno de mármol han sido hallados en los sacraria pompeyanos de las casas de Guiseppe II (VIII, 2, 39), del Vinaio (IX, 9, 6-7.10) y della Regina Carolina (VIII, 3, 14) (Bassani 2008: 132).

(38) Entre los objetos hallados in situ en el pseudoedículo de la Casa delle Pareti Rosse, en Pompeya (VIII, 5/6, 37), se encontró una lucerna en bronce con asa con forma de media luna (Boyce 1937: 77, n. ${ }^{\circ}$ 317; Figura 1). También en el sacrarium de la Villa Fondo d'Acunzo (Boscoreale) una lucerna de bronce forma parte del ajuar ritual (Bassani 2008: 133, n. 40).

(39) En el larario tipo nicho hallado en el pequeño atrio del Quartiere del Procuratore de la Casa del Menandro, en Pompeya (I, 10, 4.14-15), se encontraron tres lucernas de terracota in situ (Boyce 1937: 28, n. ${ }^{5}$ 2).

$\left({ }^{40}\right)$ Sobre el valor ritual de las lucernas en contextos religiosos en el mundo mediterráneo, véase J. Toutain en Daremberg-Saglio III, s.v. "Lucerna, lychnus", 1336-1337. En los contextos domésticos iberos la presencia de lucernas se lee en clave ritual y forma parte del conjunto de materiales indicadores de una posible actividad cultual (Bonet 1995: 390). 


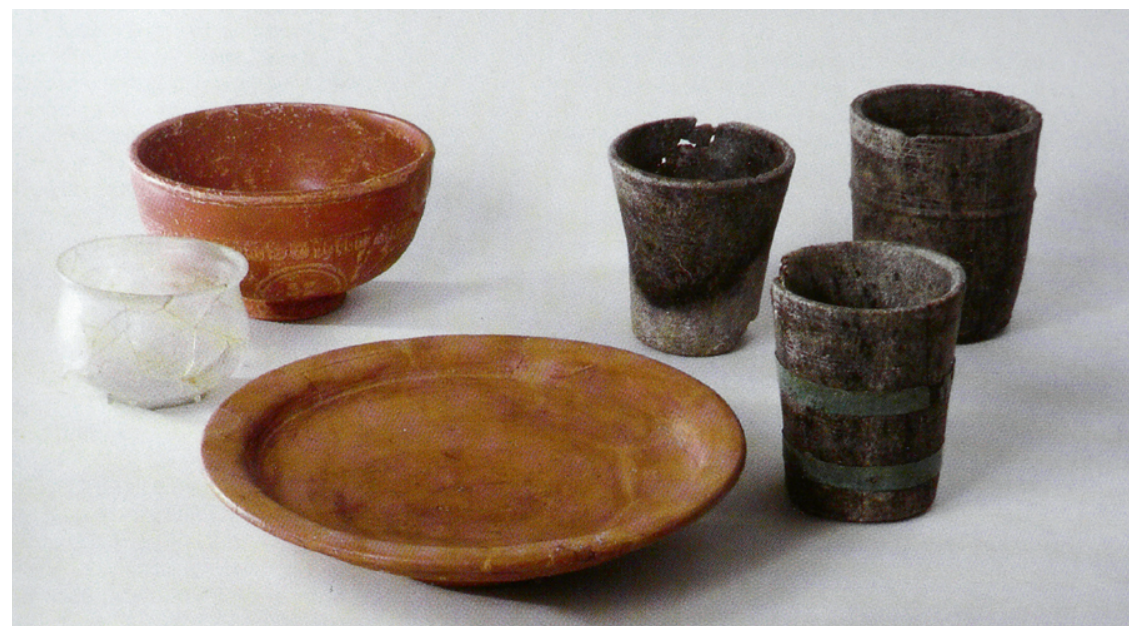

FIGURA 8. Instrumentum domesticum de uso ritual hallado en un larario de Aventicum (Avenches, Suiza). Ebnöther y KaufmannHeinimann 1996: lám. B2.

mento sagrado relacionado con numerosas creencias y supersticiones, y como tal se ofrecía a los dioses domésticos (Pers., saturae 3, 24; Hor., carm. II, 23, 20). Por extensión, su contenedor, el salinum, era considerado sagrado; era un accesorio obligatorio en la mesa y atraía la protección divina sobre los comensales (Deonna y Renard 1961: 30).

Patella y salinum eran objetos preciosos, no solo por su significado, sino incluso por su valor material (Val. Max. 4, 4, 3; Liv., ab urbe condita XXVI, 36), y como tales se transmitian de generación en generación (Hor., carm. II, 16, 13-14). Además de ellos, las fuentes escritas hacen referencia al guttus (Hor., sat. I, 6, 118) para las libaciones y al Ianx (Cic., Mos. 104) para la ofrenda de los productos del suelo (De Marchi 1896: 102).

Finalmente, de otros objetos rituales tenemos constancia a través de las escenas litúrgicas de los lararios pictóricos, como las acerrae, cajitas en la que se guardaba el incienso para los sacrificios y que aparecen como atributo del Genius doméstico (Kunckel 1974: 19); los cuchillos sacrificiales usados por los victimarii (De Marchi 1896: 102), o la flauta doble tocada por el tibicen (Figura 7).

\subsection{Instrumentum domesticum y otros materiales hallados en lararios}

La variedad de piezas del instrumentum domesticum halladas en lararios es altísima entre recipientes para contener líquidos (sítulas, jarros, botellitas, balsamarios, cráteras...), objetos de cocina (cacerolas, ollas, cestos...) y piezas de vajilla (platos, cuencos, copas, vasos, tazas...) (Figura 8). Junto a ellos se han encontrado objetos de uso personal como amuletos, anillos, fíbulas, pendientes, gemas, dados o campanillas ${ }^{41}$.

Todos ellos carecen de significado claro en el contexto específico del larario. Pudieron ser utilizados como objetos rituales subsidiarios, detrayéndolos asi temporal o permanentemente de usos cotidianos más comunes, o como ofrendas en el caso de algunos objetos personales, como ocurría, por ejemplo, con las bullae durante la celebración del paso del hijo a la edad adulta (sollemnitas togae purae). La gran diversidad de estos hallazgos impide, por otro lado, establecer posibles tipologías de materiales domésticos especialmente adecuados para el culto, de manera que solo por comparación con objetos contextualizados es posible suponer un uso ritual para otros similares, sin poder pasar del plano de la hipótesis cuando se desconoce la procedencia. Nos detendremos brevemente en algunos hallazgos especialmente interesantes y a los que se ha dedicado cierta atención.

Con frecuencia se encuentran monedas en contextos de lararios, como se ha documentado en Pompeya ${ }^{42}$ y en el agro vesubiano ${ }^{43}$, pero también en otras zonas del mundo romano, como en Hispania (vid. inf.) y en Grecia ${ }^{44}$.

Las fuentes escritas hablan de diferentes ritos de carácter doméstico y familiar en los que entraban en juego

(41) Véanse ejemplos de éstos y otros objetos en Bassani 2008: 134-136 y en Kaufmann-Heinimann 1998: 288, GF86; 294-295, GF97; 303-304, GF106.

(42) En la Casa di Obellius Firmusse halló una moneda de Calígula asociada al edículo del atrio (Boyce 1937: 31, n. ${ }^{\circ}$ 67); un as de Germánico y un sestercio de Nerón formaban parte del conjunto de objetos del larario tipo nicho ubicado en el corredor de acceso al jardín de la Casa del Cenacolo (ibid:: 37, n.o 108); en el peristilo de la Casa degli Amorini Dorati se encontró un as de Nerón en el edículo (ibíd:: 57, n. 220 ), y en el sacrarium, dos ases (Bassani 2008: 221); en la Casa del Vinaio, en el sacellum, se halló una moneda de Claudio (ibid.: 230); del sacellum de la Praedria di lulia Felix proceden cinco monedas "come di argento" (ibíd:: 219); en la casa VII, 15, 8 se encontraron un semiuncial, dos monedas de Ebusus y una hispano-púnica (Gorini 2011:248, tabla 1); en la casa IX, 8, 8, un bronce de Neapolis y un semiuncial de Roma (ibíd.).

(43) Del sacrarium de la Villa Fondo d'Acunzo (Boscoreale) proceden seis denarios de plata y otras 35 monedas de época imperial (Bassani 2008: 126, 212).

(44) En el sacrarium de la Casa excavada en la C/ Boukaouri de Patrás se encontraron numerosas monedas junto con otros materiales asociados al culto (Bonini 2011: 208). Otros hallazgos en casas de Grecia hacen referencia a manifestaciones de culto doméstico, si bien no proceden de lararios; se trata de monedas insertas en muros o bajo columnas, a los que se les ha dado un valor ritual de tipo apotropaico (ibid:: 216). De forma similar, en una casa de Patavium (Padua, Italia), se encontraron monedas junto con huesos de perro en el nivel de fundación (Gorini 2011: 249). 




ム Figura 9. Escultura en bronce de Mercurio acompañado de un gallo, de Trento (Italia). Obsérvese la ranura en la parte superior del pedestal.Kaufmann-Heinimann 1998: 168, fig. 114.

monedas, como la sollemnitas togae purae (De Marchi 1896: 144), la boda (Samter 1901: 19) o el funeral (Toynbee 1971: 44). Se trata de tres ritos de paso en los que se ofrecian monedas, en la boda directamente a una divinidad doméstica, el Lar familiaris, por parte de la novia.

Precisamente en relación con el uso de monedas como ofrendas pecuniarias a los dioses domésticos, en el matrimonio y otos ritos, creemos que hay que poner un conjunto de piezas al cual ha atendido A. Kaufmann-Heinimann (1998: 168-180). Se trata de esculturas en bronce con ranuras en ellas mismas o en los pedestales -entre las que destaca el alto número de representaciones de Mercurio- e incluso verdaderas huchitas (Figura 9). Una de estas piezas singulares ha sido encontrada en el sacrarium de la Villa de Vilauba (Camós, Gerona), donde también se han documentado seis monedas (vid. inf.).

Kaufmann-Heinimann (1998: 174) propone que la finalidad de estas ofrendas fuera obtener fortuna y bienestar, a partir de una escultura con ranura perteneciente a una corporación de aerariy valorando también que las esculturas de Mercurio son las utilizadas más comúnmente como huchas.

Pero se debe contemplar también la hipótesis de Ernst Samter (1901: 24-25) sobre el valor censal de las monedas en los ritos familiares. El autor hace referencia a la donación de una moneda en el templo de Juno Lucina cada vez que nacía un niño, en el templo de luventas cuando el niño alcanzaba la madurez, en el templo de Juno Libitina cuando se producia una muerte y en el compitum y en el fuego del hogar -en ambos casos a los Lares- por parte de la esposa durante la ceremonia de la boda. A partir de esto, propone la hipótesis de que estas monedas fuesen la forma de congraciarse con la divinidad bajo cuya protección se pasaba a estar en esos momentos de tránsito, así como que sirviesen para hacerla partícipe de que tenía una nueva alma a su cargo. La presencia de monedas en los lararios podría haber tenido este valor censal, para hacer conocedores a los dioses domésticos de las personas que tenían a su cargo.

También debe contemplarse el valor de amuleto y talismán que se le daba a la moneda en la Antigüedad, tanto por la forma redonda como porque a algunos de los materiales usados para su fabricación, como el bronce, se les otorgaban propiedades protectoras (Pera 1993: 347-349).

Por otro lado, en dos textos que distan siete siglos entre sí -el Aulularia de Plauto del s. III-II a.C. (Plaut., Aul., pról.) y el Querulus, últimamente atribuido a Rutilio Namaziano y datado en el primer cuarto del s. V d.C. (Quer. III, 46)- se presenta el espacio sacro doméstico como el lugar en el que se guardaba el tesoro de la familia, protegido por el Lar familiaris (Bassani 2008: 55-56). Giovanni Gorini (2011: 246) ha puesto estos textos en relación con los depósitos de monedas hallados en casas de época romana, como la Casa de la Rotonda, en Cartago (Túnez), donde se ha encontrado un tesoro de 301 monedas relacionadas con el larario; también en la Casa di un Flamine de Pompeya $(\mathrm{V}, 4,3)$, en un armario en el atrio, donde también había un larario tipo nicho, se documentó un conjunto de 130 monedas de plata y 54 de bronce, mientras que en otro adyacente estaban las imágenes de culto $^{45}$ (Boyce 1937: 40, n. ${ }^{\circ} 118$, n. 1; Kaufmann-Heinimann 2007a: 153). Estos tesoros recuerdan a los thesauroi que se ofrecian en los santuarios a los dioses -como hacian los Fratres Arvales durante el sacrificio a la Dea Dia ${ }^{46}-$, modelo

${ }^{45}$ Véanse otros ejemplos, como el posible ocultamiento de un tesoro con monedas junto con imágenes de culto en una casa de Lugdunum (Lyon, Francia), en Kaufmann-Heinimann 1998.

${ }^{(46)}$ Recordamos que en el Carmen Fratrum Arvalium se encuentra la primera invocación a los Lares, en la que autores como G. Wissowa (en Roscher, ML II.2., s.v. "Lares", 1888-1889) se han apoyado para defender el origen agricola del Lar familiaris. 


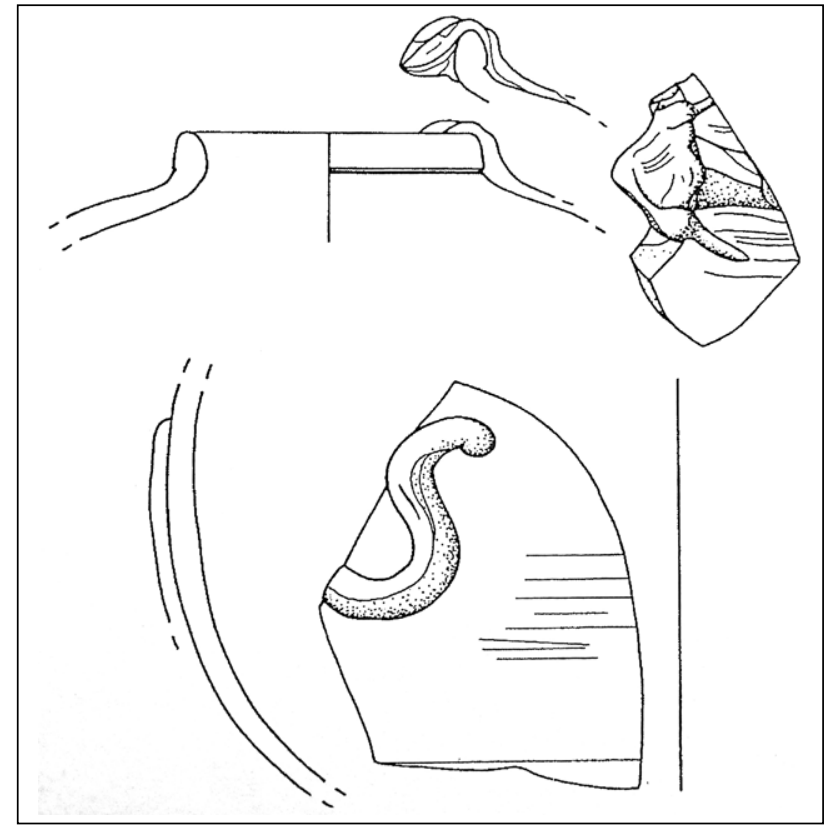

A Figura 10. Fragmentos de ollas cerámicas con decoración plástica de serpientes, halladas en el larario de la insula 5/9 de Augusta Raurica (Augst, Suiza). KaufmannHeinimann 1998:86, fig. 44.

quizá para esta práctica privada de encomendar la pecunia a los dioses domésticos (Gorini 2011: 247, 250), que, por otro lado, eran los encargados de proteger la casa, la familia y todo lo que tuviese que ver con su subsistencia.

Francesco Di Capua (1950: 78-81) hace referencia a otros curiosos materiales encontrados en lararios pompeyanos y herculaneses, como bolitas de mármol, conchas, dados, medias lunas, espejos o vasitos ${ }^{47}$. A partir del testimonio de Apuleyo (Apul., Apol. 55-56), los interpreta como sacrorum crepundia, emblemas y recuerdos que poseían los iniciados en los ritos mistéricos y que en ocasiones se conservaban en los lararios como "signa et memoracula" de la iniciación. Como tales considera los objetos -entre ellos 373 piezas de coral- que aparecieron en el peristilo de la pompeyana Casa di M. Gavius Rufus (VII, 2, 6) junto con varias imágenes de divinidades, todo asociado a dos grandes nichos; da también noticia del hallazgo de un arcula con muchos crepundia guardada en un armario cerrado dentro del cubiculum del villicus en una villa de Boscoreale. Por otro lado, sobre las bolitas de diferentes materiales halladas en lararios, Maddalena Bassani (2008: 133-134) ofrece una lectura alternativa como elementos apotropaicos, basándose en la creencia antigua de que los espíritus maléficos no podían penetrar en ningún objeto redondo.

Otro conjunto interesante de materiales son las ollas con decoración plástica de serpientes procedentes de $A u-$ gusta Raurica (Augst, Suiza; Figura 10), algunas de ellas encontradas en contextos de lararios ${ }^{48}$ (Kaufmann-Heinimann 1998: 159-162), y de otros yacimientos de la Galia Bélgica y Germania. A partir de las halladas en santuarios parece demostrarse que su uso fue ritual, en relación con el culto a divinidades de la tierra y, en particular, a Mitra (Joly 2007: 108). La presencia de la serpiente en contextos de larario es también común, como puede apreciarse en los lararios pictóricos pompeyanos (Figura 7), si bien en este caso no se relaciona con cultos mistéricos, sino con la representación de un genius loci, de la versión zoomorfa del Genius del paterfamilias o de los antepasados familiares, opción esta última que hemos defendido en otras sedes (Pérez Ruiz 2011a: 210-212 y 2011b).

\section{MATERIALES ASOCIADOS AL CULTO DOMÉSTICO EN LAS PROVINCIAS BAETICA Y TARRACONENSIS}

De las 48 estructuras para el culto doméstico documentadas entre las provincias Baetica y Tarraconense en época romana, solo en ocho procedentes de la segunda provincia se han documentado materiales asociados. A pesar de ser un número bajo de lararios, la diversidad de los materiales es alta, de forma similar al panorama trazado para el conjunto del mundo romano. Se da además el caso de que, entre estas estructuras, dos de época republicana responden a tradiciones locales ${ }^{49}$ y no a la itálica del larario, cuyos primeros testimonios en Hispania son del s. I a.C.; los materiales hallados en ambas estructuras tampoco son itálicos.

Además de los objetos hallados en estos espacios de culto, deben tomarse también en consideración algunos otros, esculturas y aras, encontrados en casas pero cuya asociación a espacios para el culto se desconoce o no existe. A pesar de esto, la procedencia de viviendas y sus características formales e iconográficas hacen probable que se trate de materiales de culto doméstico, como se ha visto. Algunos de estos materiales proceden también de la Bética, si bien de nuevo la mayoría son tarraconenses.

$\left({ }^{47}\right)$ Una bola de mármol en un peculiar sacrarium ubicado en una cueva bajo el patio detrás del atrio de la Casa VIII, 2, 14.16 de Pompeya (Boyce 1937: 74, n. ${ }^{3}$ 344). Una concha en el larario de la Casa di Guiseppe II, también en Pompeya (VIII, 2, 39). Un espejo en la Villa Fondo d'Acunzo (Boscoreale), en un larario con numerosos materiales (Bassani 2008: 126, tabla 12).

${ }^{(48)}$ En el larario D2 de la insula 5/9 se hallaron dos de estas ollas junto con varias esculturas en bronce de divinidades domésticas (KaufmannHeinimann 1998: 86-87; 278, GF70; Figura 10).

(49) Se trata una de las estancias de la Casa del Sector 4-C de Ilici (La Alcudia de Elche, Alicante) y de la habitación principal de la Casa n. 1 de Mas Castellar de Pontós (Gerona). Para la primera, véase Ramos Fernández 2001-2002: 117-126. Para la segunda, véase Pons et al. 2002: $120-121,129,401$. 

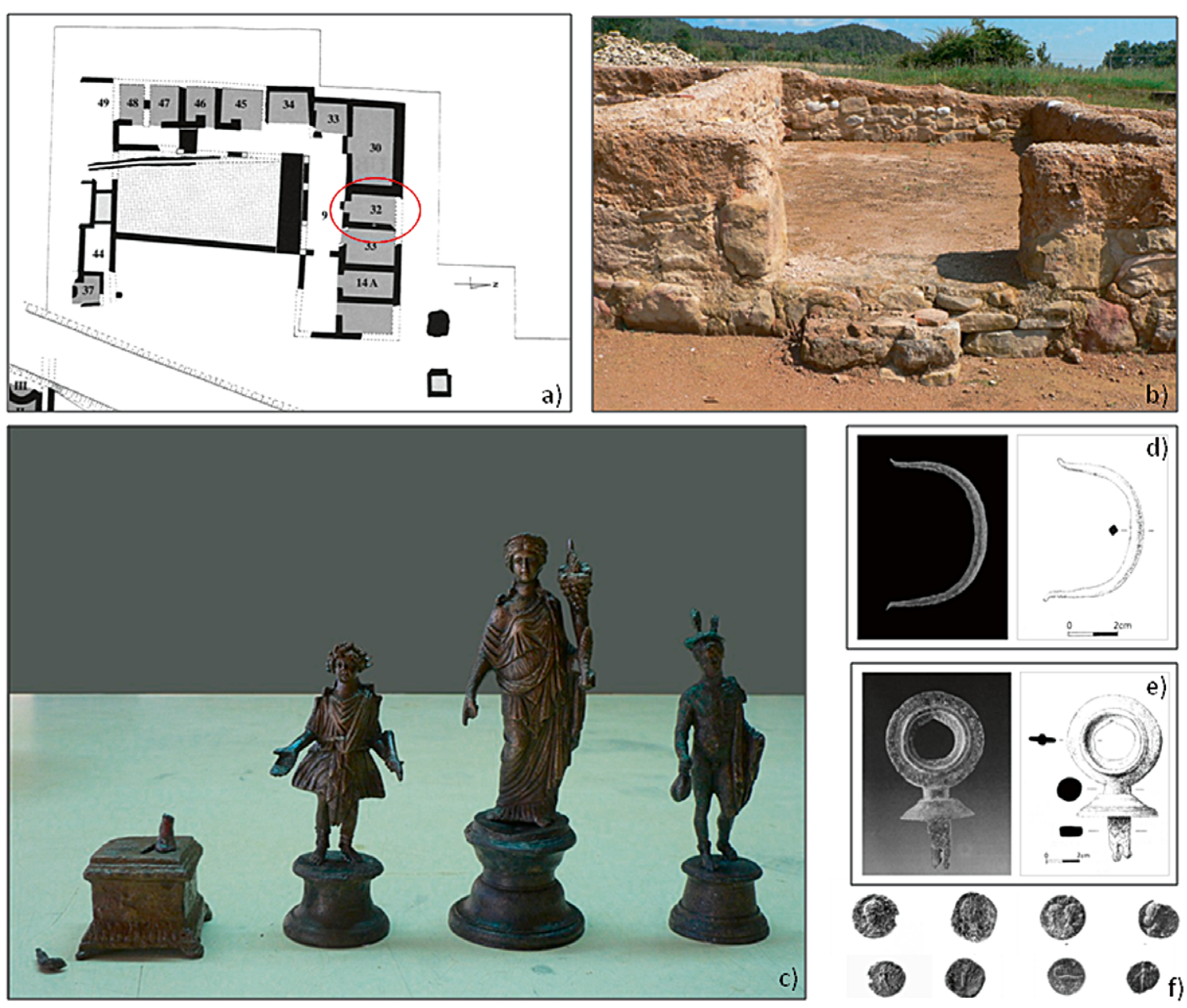

c)

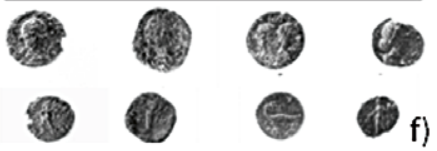

A Figura 11. Larario de la Villa de Vilauba (Camós, Gerona) y materiales encontrados en su interior. a) Planta de la villa, con ubicación del larario. b) Larario abierto al peristilo. c) Esculturas en bronce. De izda. a dcha.: Silvano (?), Lar, Fortuna, Mercurio. d) Asa de mueble en bronce. e) Pomo de puerta en bronce. f) Monedas. a) Castanyer y Tremoleda 1999: 54, fig. 29; b-c) M. Pérez Ruiz; d Castanyer y Tremoleda 1999: 61, fig. 39; e) ibíd.: 61, fig. 38; f) ibíd.: láms. 126.3, 126.4, 126.5, 126.6.

\subsection{Imágenes de culto}

Se han hallado imágenes de culto en tres lararios tarraconenses. En dos de ellos se trata de esculturas realizadas en bronce -cinco en total- y en el tercero de fragmentos de una en piedra.

De las esculturas en bronce, cuatro responden al formato típico de las llamadas "esculturas de larario". Repre- sentan al Lar, Mercurio, Fortuna y probablemente Silvano ${ }^{50}$ y proceden del sacrarium de la Villa de Vilauba (Camós, Gerona), donde debieron de estar colocadas en un nicho en la pared ${ }^{51}$ (Castanyer y Tremoleda 1997; Castanyer y Tremoleda 1999: 62-64; Kaufmann-Heinimann 1998: 227-228). Por el momento, este es el único grupo de esculturas de este tipo que tienen como contexto de procedencia un larario en las provincias analizadas (Figura 11).

${ }^{(50)}$ Se han conservado solo la cola y una pezuña. Por las huellas de soldadura en el pedestal se sabe que se trata de una figura bipeda, pero con pezuñas de ungulado en lugar de pies. Ello y la cola nos llevan a proponer que la imagen representada fuera Fauno o, más bien, Silvano 0 Pan, ya que Fauno habría comenzado a ser representado de forma icónica por sincretismo con éstos (Pouthier y Rouillard en LIMCVIII.1, S.v. "Faunus", 582-583; Pouthier y Rouillard 1986). Una escultura en bronce de Pan, mitad humano y mitad caprino, perteneciente a una colección privada neoyorquina, puede servir como modelo de referencia para la de Vilauba (LIMCVIII.2, s.v. "Pan", fig. 108). Algunos autores consideran que Silvano y Pan no se diferencian en absoluto desde el punto de vista iconográfico (Bulard 1923: 159-163), aunque el primero puede aparecer representado también de forma totalmente antropomorfa. A. Kaufmann-Heinimann (1998: 193, fig. 139) recoge muy pocos casos de esculturas en bronce de pequeño formato procedentes de lararios de Pan y ninguno de Silvano, pero este aparece asociado al culto doméstico en otros contextos (véase Bulard 1923 para Delos; Bakker 1994: 228, n. 60 para Ostia y Dorcey 1992: 24 para Carnuntum). Esto, unido a la dimensión doméstica de Silvano, como divinidad complementaria del Lar (Bulard 1923: 463-478; Dorcey 1992: 24-25, 135-144; Pérez Ruiz 2008: 284-285), nos lleva a proponer que fuese esta la divinidad representada en Vilauba.

(51) Agredecemos al Dr. Pere Castanyer su amabilidad y sus explicaciones al mostrarnos el larario y los materiales asociados. 



\ Figura 12. Larario de la Villa de Cornelius (L’Enova, Valencia) y materiales encontrados en su interior. a) Planta de la villa con ubicación del larario. b) Sacellum construido en el jardín. c) Cabecita en mármol de Hércules. d) Fragmento de ara con inscripción dedicada a Hercules Invictus. e) Monedas. a) Albiach y Madaria 2006: 70; b) ibíd.: 73; c) ibíd.: 74; d) ibíd.: 65, n. ${ }^{\circ}$ 1; e) ibíd.: 118, lám. 5, nos $41,44,45,47$ y 48.

En la Casa de la Cabeza de Bronce, en Pollentia (Alcudia, Mallorca), se halló en cambio una cabeza infantil, también en bronce, probablemente de Dioniso/Baco (Moreno et al. 2011: 931-933). Formaba parte de un pequeño depósito de bronces acumulado en la misma habitación en la que se ha documentado una estructura que hemos interpretado como el arranque del podium de un edículo (Arribas et al. 1973: 83-90; Pérez Ruiz 2010, vol. II: 210-212). Aunque no es frecuente, existen otros lararios con cabezas y bustos de divinidades entre sus materiales. En el larario de una de las casas de la Insula 5 de Augusta Raurica (Augst, Suiza) ha aparecido un busto de Baco coronado con una parra, junto con otro de Hércules niño, con una clava ${ }^{52}$ (Kaufmann-Heinimann 1998: 143-144).

Finalmente, una cabeza en mármol blanco de Hércules joven procede del sacellum de la Villa de Cornelius, en
L'Énova (Valencia) (Albiach et al. 2006: 72-74). Otro Hércules iconográficamente similar se encontraba en el edículo de la Casa delle Pareti Rosse, en Pompeya (VIII, 5, 37; AdamoMuscettola 1984, 16, fig. 9), y se corresponde con una de las variantes de representación de Hércules Invicto en los contextos domésticos de culto (Coralini 2001: 59). Precisamente, este epiteto aparece en el epígrafe dedicado al héroe también en el larario de la Villa de Cornelius (Corell 2006: 135-136, n.o 81) (Figura 12).

Otras nueve esculturas que hemos interpretado como imágenes de culto proceden de casas, pero carecen de asociación a espacios de culto; cinco de ellas están realizadas en bronce y cuatro en piedra.

En cuatro de las cinco esculturas en bronce se representa a Mercurio, todas procedentes de villas tarraconen-

(52) La cabeza de Pollentia, sin embargo, presenta un problema en la comparación con estos bronces, ya que el sistema de despiece del cuello no es propio de bustos, sino más bien de cabezas trabajadas por separado en estatuaria broncínea ideal de medio formato (Moreno et al. 2011: 933, n. 38). 
ses. Una de ellas se halló en la Villa de L'Alter (Chilches, Castellón; Baratta 2001: 123; Mesado 1971: 169-171); otra en la parte residencial de la Villa de El Villar (Coy, Murcia; Martínez Rodríguez 1991-1992: 210-211); otra más en la villa de Balsapintada (Valladolises, Murcia), enterrada junto al muro de una habitación (Ramallo y Ros 1988: 162-164), y una pierna y el pedestal de otra entre los materiales de derrumbe del segundo piso de la Villa de Veranes ${ }^{53}$ (Gijón, Asturias). La quinta escultura representa al Genius y procede de un contexto doméstico -seguramente rural- hallado en Ponte Puñide (Gonzar, 0 Pino, La Coruña; Rodríguez Garcia 1999: 147-148).

También entre las esculturas en piedra hay dos de Mercurio, ambas fragmentarias. Una de ellas, en mármol blanco, procede de una domus en la Plaça del Rei de Barcelona, probablemente del atrio o el peristilo (Beltrán de Heredia 2001: 154, n. ${ }^{0} 73$ ). La otra, en alabastro local, fue hallada en una de las estancias de representación de la Casa de Hércules, en Celsa (Velilla de Ebro, Zaragoza; Beltrán Lloris 1998: 123, n. ${ }^{\circ}$ ). Ambas piezas son de pequeñas dimensiones.

Otra de estas esculturas, en mármol blanco, representa a Fortuna ${ }^{54}$ (Koppel 1993: 227) y procede de una villa junto al río Francoli (Tarragona). La parte trasera está trabajada someramente, por lo que debió de estar colocada en un nicho o en un edículo (Figura 13). Si bien el tipo iconográfico de Fortuna de esta escultura no es el más común en los lararios, hay una imagen similar en el larario de la Casa della Fortuna en Pompeya (IX, 7, 20; Kaufmann-Heinimann 1998: 225, GFV45).

La última escultura pétrea, de mármol, procede del Convento de los Santos, en Zuera (Zaragoza), si bien se desconoce el contexto exacto (Beltrán Lloris y Paz 2003: 140). Proponemos un uso ritual doméstico en función de su iconografía, ya que representa a una serpiente reptando por una roca y enroscándose a un altar coronado por un huevo, imagen frecuente en los lararios pictóricos pompeyanos (Fröhlich 1991: 298, L109). También se han documentado esculturitas que representan serpientes en lararios (Kaufmann-Heinimann 1998: 215, GFV9), pero no en composiciones similares a la de Zuera.

Si se compara este grupo de esculturas tarraconenses con el panorama presentado para el conjunto de imágenes de culto doméstico del mundo romano, se observa que los casos hispanos encajan en él sin estridencias.

En lo que se refiere a materiales de fabricación, a pesar de que no se da la misma variedad que se ha visto, por ejem-



$\Delta$ Figura 13. Escultura sedente de Fortuna hallada en una villa junto al río Francolí (Tarragona).García y Bellido 1949, vol. II: fig. 168 .

plo, en Pompeya, predominan dos de los materiales más comunes, el bronce y el mármol. En cambio, no se ha documentado por el momento el uso de la terracota en esculturas halladas en lararios, más frecuente incluso que el mármol en los lararios pompeyanos (Kaufmann-Heinimann 2007a: 155). Algunas esculturas de este material encontradas en espacios domésticos se han dejado al margen de este estudio, ya que pudieron haber desempeñado otras funciones además de la religiosa y carecemos de indicios suficientes para suponerles este uso.

(53) Inédito. Agradecemos a la Prof. Carmen Fernández Ochoa la información facilitada sobre esta pieza.

${ }^{(54)}$ Otros autores han interpretado esta escultura como una representación de Ceres (García y Bellido 1949, vol. 1: 157, n. ${ }^{168 ;}$ Ventura 1942: 133). La comparación con los tipos iconográficos de ambas diosas parece demostrar, sin embargo, que la identificación como Fortuna es más acertada, ya que la figura coincide con las representaciones de Fortuna sedente en un trono, vestida con chiton e himation y provista de la cornucopia y el timón o la pátera (Rausa en LIMCVIII.1, s.v. "Tyche/Fortuna", 131-132), atributo que, en el caso de la escultura de la villa del Francoli, no se ha conservado, ya que el antebrazo derecho se ha perdido. Como peculiaridad, la pieza estudiada tiene la cabeza velada, algo que no siempre ocurre en las Fortunas de este tipo. 


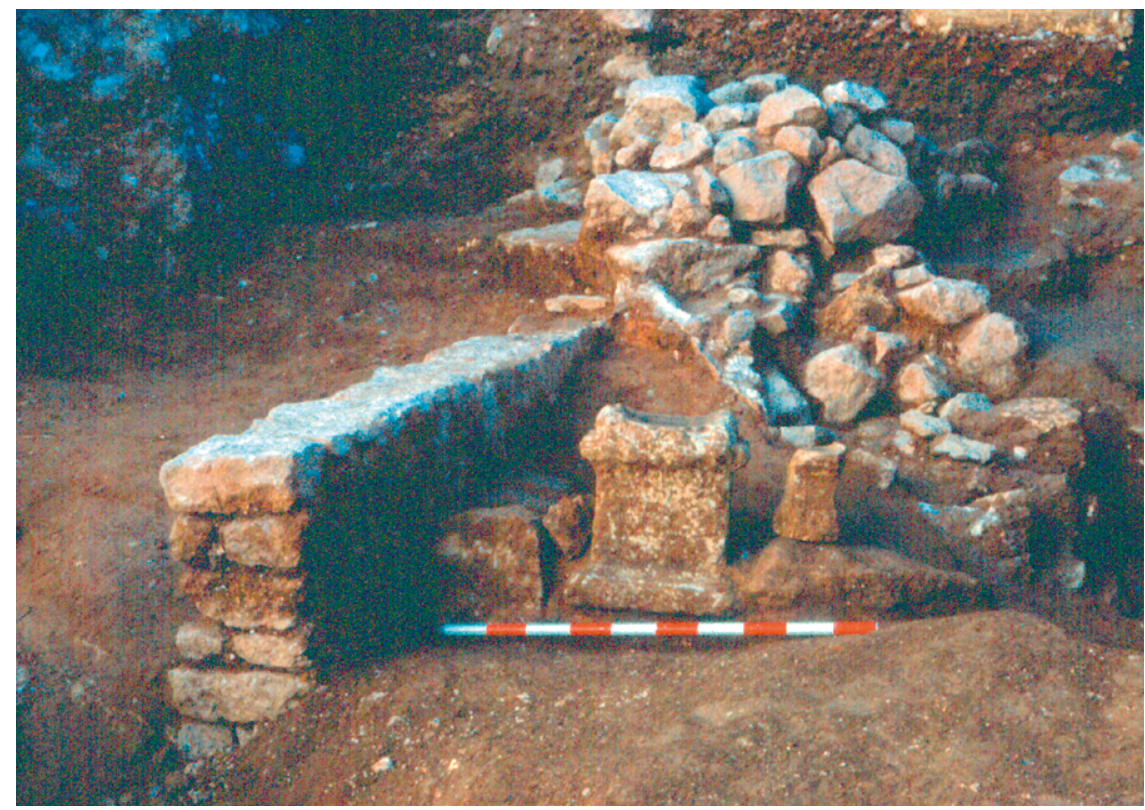

Figura 14. Árulas de la Casa de la Plaza de San Ginés (Cartagena, Murcia), halladas en el espacio del jardín seguramente destinado a sacellum. () Archivo Fotográfico del Museo Arqueológico Municipal de Cartagena, n. ${ }^{0} 1129$.

En cuanto al tamaño, son todas de pequeño formato, desde los $7 \mathrm{~cm}$ del Mercurio de la Villa de Balsapintada (Valladolises, Murcia), hasta los $35 \mathrm{~cm}$ de la Fortuna de la villa junto al Francoli (Tarragona); en esto se ajustan también a la media general. No se han documentado esculturas de gran formato como algunas pompeyanas ${ }^{55}$.

También las divinidades representadas encajan en términos generales con lo visto para el conjunto del mundo romano. Solo Silvano no aparece en el cuadro general trazado por A. Kaufmann-Henimann (1998: 193, fig. 138) que hemos tomado como referencia, si bien Silvano y Pan pueden ser iconográficamente equiparables ${ }^{56}$ y del segundo sí se recoge algún testimonio. La serpiente forma parte del conjunto de imágenes que, sin ser divinidades, podian poblar los lararios, si bien la iconografía de la escultura de Zuera es más propia de las representaciones pictóricas que de las escultóricas. Mercurio, la divinidad más representada en el conjunto hispano, es la segunda a nivel general, mientras que llama la atención la documentación de un único Lar contextualizado, pues es la divinidad escultóricamente más representada en lararios.

Por lo que se refiere a la cronología, cabe destacar que, si bien según A. Kaufmann-Heinimann la mayoría de los contextos de lararios con esculturas se amortizan en el s. Ill d.C., el Mercurio de la Villa de Veranes (Gijón, Asturias) procede de niveles del s. IV d.C. y el sacellum de la Villa de Cornelius (L'Énova, Valencia) en el que se ha encontrado la cabecita de Hércules se amortizó también en ese siglo (Albiach et al.2006: 135-136). El conjunto de bronces de
Vilauba (Camós, Gerona) se ha fechado estilisticamente en el s. I d.C., pero su uso como imágenes de culto de la villa se mantuvo hasta el s. III, en que un incendio la destruyó parcialmente (Castanyer y Tremoleda 1997: 174); son, por tanto, un buen ejemplo de la continuidad de uso de este tipo de materiales. Las demás esculturas o sus contextos arqueológicos se fechan entre los ss. I y III d.C.

\subsection{Objetos rituales}

En este apartado debemos comenzar nuevamente hablando de las aras y las árulas, pues además del valor que tienen como indicadores de una actividad religiosa doméstica, aunque no estén asociadas a espacios de culto, se trata del tipo de objeto ritual más frecuente en las provincias Baetica y Tarraconensis, si bien la mayoría de los testimonios proceden de la segunda.

Se han documentado seis aras y árulas en tres lararios tarraconenses, en dos de ellos anepigráficas y en el tercero una con epígrafe y otra sin él. Todas ellas están realizadas en piedra.

En la Casa de la Plaza de San Ginés, en Cartagena (Murcia), excavada parcialmente, ha sido precisamente el hallazgo de un ara y dos árulas lo que nos ha llevado a interpretar como cultual el pequeño espacio triangular en el que se encontraron, en la zona de unión de dos muros de cierre y seguramente al aire libre ${ }^{57}$ (Martín Camino y Roldán 1997: 128; Figura 14). En el pasillo de acceso a la Casa de la Fortuna, en Bilbilis (Calatayud, Zaragoza), se ha documen-

(55) En la Lusitania, en cambio, se halló un Lar de piedra de casi $1 \mathrm{~m}$ de altura que consideramos una imagen de culto doméstico (Pérez Ruiz 2008)

(56) Véase lo dicho al respecto en la n. 50.

(57) Agradecemos a Miguel Martín Camino y al Museo Arqueológico Municipal de Cartagena la información proporcionada al respecto de estas piezas. 


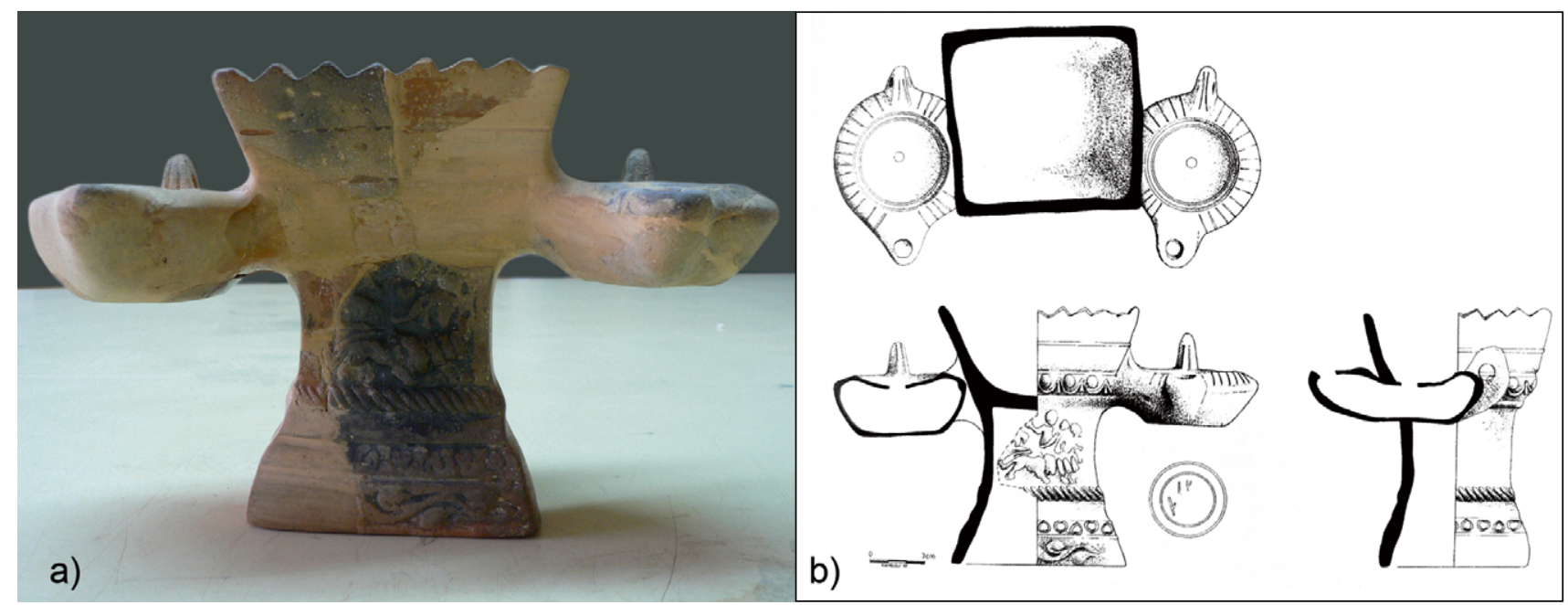

A FiguRA 15. Árula hallada en la despensa de la Villa de la Vilauba (Camós, Gerona). a) M. Pérez Ruiz; b) Castanyer y Tremoleda 1999: 285 , fig. 176.

tado un larario pictórico en el que se representa a Fortuna $y$, bajo este, una repisa sobre la que estaba la mitad inferior de un árula anepigráfica de piedra caliza (Martín Bueno 1975-1976: 169-171; 1979: 300-301, n. 3; Guiral y Martín Bueno 1996: 235-245). Finalmente, en la Villa de Cornelius, en L'Énova (Valencia), se han encontrado fragmentos de dos aras, una con una inscripción dedicada a Hércules Invicto ${ }^{58}$ (Figura 12d), en el interior del sacellum, y otra anepigráfica, al exterior (Figura 12b).

En otros casos, las árulas proceden de casas donde se han documentado espacios de culto, pero no directamente asociadas a ellos. Han aparecido también en viviendas en las que se han encontrado otros materiales o manifestaciones rituales, como enterramientos infantiles o depósitos rituales, en muchos casos sin relación directa. La mayoría, sin embargo, son el único testimonio de actividad ritual en el espacio doméstico, que además en el caso de las epigráficas informa muchas veces sobre la divinidad venerada. Suman por el momento 54 aras y árulas ( 11 de las primeras y 43 de las segundas) halladas en viviendas urbanas y rurales, 33 anepigráficas ${ }^{59}$ y 21 con epigrafía. Tres más sin contexto conocido presentan epígrafes o decoraciones que ofrecen cierta seguridad sobre su uso en el culto doméstico ${ }^{60}$.
De buena parte de estas aras y árulas no se conoce el lugar exacto del hallazgo dentro de la vivienda y para las que si se sabe, este resulta dispar, de lo que parece desprenderse que no existía una ubicación preferente para situarlas dentro de la casa o, dicho de otra forma, que cualquier espacio doméstico era susceptible de albergar el ritual religioso, aunque fuera de forma temporal.

La mayor parte de estos objetos de culto están realizados en piedra, normalmente local, si bien contamos con dos excepciones para las que se utilizó la terracota ${ }^{61}$ (Figura 15); la diferencia con lo conocido para Pompeya es, por tanto, notable. En cuanto a las dimensiones, oscilan desde los $6 \mathrm{~cm}$ del árula de la Villa de Maternus, en Carranque (Toledo), hasta los $45 \mathrm{~cm}$ del ara de la Casa de la Plaza de San Ginés ${ }^{62}$, en Cartagena (Murcia), en el caso de las árulas anepigráficas; las epigráficas abarcan desde los $9 \mathrm{~cm}$ de un árula procedente de Clunia (Peñalba de Castro, Burgos) y dedicada a las Matres (Palol y Vilella 1987: 30, n. ${ }^{\circ}$ 17) hasta los $87 \mathrm{~cm}$ de un ara dedicada a los Lares, Tutela y el Genius en Tarragona (CIL II, 4082; RIT, 20, n. ${ }^{\circ} 37$; Comes y Rodá 2002: 237, n. ${ }^{\circ} 75$ ).

La mayoría de las aras y árulas tienen forma de paralelepípedo ${ }^{63}$. A partir de ahí, los detalles formales varian, con bases y coronamientos delimitados por molduras o no, con 0

(58) Según J Corell, Invictus es el epíteto más frecuente entre los atribuidos a Hércules en la Península Ibérica (Corell 2006: 136).

(59) En cinco casos no se conoce con exactitud si proceden de una vivienda, pero en las excavaciones en las que se han hallado se han documentado también estructuras domésticas. Se trata de tres árulas halladas en la Plaça del Rei de Barcelona (Beltrán de Heredia 2001: 155, n. ${ }^{\circ} 75,76,77$ ) y dos en la C/ Fortuny de Tarragona (Montón 1996: $32, n .{ }^{\circ} 4 ; 38, n .^{\circ} 19$ ).

$\left.{ }^{60}\right)$ Árula de Itálica (Santiponce, Sevilla) con representación de serpientes acercándose a un altar con ofrendas, similar a las de los lararios pictóricos (CILA3 1991: 34-35, n. 360; Martínez Munilla 1950). Árula de Uxama Argaela (Burgo de Osma, Soria) dedicada a Júpiter Óptimo Máximo (García Merino 2001, 128-129), divinidad más común en los epigrafes de culto doméstico aquí estudiados. Árula encontrada en Sagunto (Valencia) y dedicada a los Lares por un ostiarius (CIL II2/14.587; Corell 2002: 429-430, n. ${ }^{333}$ ).

${ }^{(61)}$ Árula con lucernas adosadas y decorada en el cuerpo con el desfile triunfal de Cibeles y Attis, hallada en la despensa de la Villa de Vilauba (Camós, Gerona) (Castanyer y Tremoleda 1999: 284-286; Ruiz de Arbulo 1996: 117, 121; Figura 15). Árula decorada con un pseudoepígrafe y procedente del lado 0 del peristilo de la Villa de Maternus en Carranque (Toledo) (Inédita. Agradecemos al equipo del Proyecto Carranque la información que nos ha facilitado).

(62) Para las piezas a las que se alude más de una vez, véase la bibliografía en la primera alusión.

${ }^{63}$ S Son excepción a esta regla el árula de la Villa de la Ermita de San Bartolomé (Atalaya del Cañavate, Cuenca; Gimeno 2009: 166-167) y de la Villa de Maternus (Carranque, Toledo), de forma troncopiramidal, y la de la Villa de Vilauba (Camós, Gerona), troncopiramidal invertida. Otras se conservan en estado demasiado fragmentario como para poder determinar su forma con exactitud. 




\ FIgURA 16. Árula dedicada a Júpiter Óptimo Máximo Conservador, de la Villa de los Villares de Santervás del Burgo (Fuentearmegil, Soria). Jimeno 1980: lám. VIII.2.

sin pulvini y foculus, etc. ${ }^{64}$; de manera que las características formales de estas piezas no permiten definir tipos estándar de aras o árulas para el culto doméstico, pues aunque puede establecerse una tipología, esta es muy genérica (Pérez Ruiz 2010, vol. I: 447, 484).

En cuanto a la decoración, además de los diferentes tipos de molduras usados en las bases y en los coronamientos, algunas piezas presentan relieves en el cuerpo, como motivos geométricos ${ }^{65}$, guirnaldas y objetos rituales ${ }^{66}$, animales $^{67}$, pseudoepígrafes ${ }^{68}$ e incluso escenas narrativas ${ }^{69}$ (Figura 15). Algunas de ellas conservan también restos del estuco que las recubría ${ }^{70}$. En algunos casos, las aras y árulas presentan también huellas de combustión ${ }^{71}$.

Muchas de estas arae y arulae -entre ellas todas las que presentan epígrafes- fueron fabricadas y usadas en algún momento entre los siglos I y III d.C., con algunos casos que se alargan hasta el s. IV. Un reducido grupo de cinco piezas anepigráficas concentradas en la zona catalana ${ }^{72}$ presenta, sin embargo, una cronología algo más temprana, que abarca desde finales del s. II a.C. hasta el s. I d.C.; esto las convierte en el tipo de material para el culto doméstico de tradición itálica más antiguo documentado en la Bética y la Tarraconense.

Por lo que respecta a las piezas con inscripción, en la mayoría de ellas se especifica la divinidad o divinidades a las que están dedicadas, principalmente dioses domésticos y del panteón romano en general, entre los que destacan Júpiter Óptimo Máximo (Figura 16) y los Lares. Las únicas divinidades indígenas documentadas con seguridad son las Matres, a las que se dedican dos árulas domésticas en Clunia, fechadas en el s. II d.C. (Palol y Vilella 1987: 30, n. ${ }^{0} 16$, n. 17). En Segóbriga (Saelices, Cuenca), en cambio, se ha documentado un ara dedicada a Zeus Theos Megistos por el procurator Augustorum de la Citerior, C. Iulius Sylvanus, natural de Esmirna; el ara debió de formar parte del sacrarium (hieron en la inscripción) de su casa, también documentado (Abascal y Alföldy 1998: 157; Abascal 2000: 25). Estos testimonios de divinidades no itálicas son, como señala J. M. Abascal (2000: 26-27) en relación con Zeus Megistos, una muestra de la convivencia pacífica en la Hispania romana

(64) Véanse como ejemplos de diferentes soluciones formales un árula de la Casa n. 2 de Clunia (Palol y Vilella 1987: 30, n. ${ }^{\circ} 17$ ) y otra de la Villa de los Quintanares (Osa de la Vega, Cuenca) (Abascal 1998: 260-261, n. ${ }^{\circ}$ 2; Baratta 2001: 26, T8).

(65) Una de las árulas de la Casa de la Plaza de San Ginés, en Cartagena, está decorada con una estrella en la cara frontal. La de la Casa de la Fortuna, en Bilbilis, presenta una combinación de triángulos (¿tetractys mística?).

${ }^{(66)}$ Véase una de las árulas de la Plaça del Rei, en Barcelona (Beltrán de Heredia 2001: 155, n. ${ }^{\circ}$ 76), la de la Villa de Els Munts (Altafulla, Tarragona) (Gamer 1989: 271, T 20; Montón 1996: 36, n. 15) o la dedicada a los Lares, Tutela y el Genius en Tarraco.

$\left.{ }^{67}\right)$ Un gallo, un cervatillo y una cabeza de toro, junto con un kantharos, aparecen en el árula encontrada en la Villa de Puypullin (Huesca) (Gamer 1989: 234, n. HU1; Gurt 1985: 153-156). Un árula de Itálica (Santiponce, Sevilla) está decorada con dos serpientes acercándose a un altar con ofrendas (Martinez Munilla 1950)

${ }^{(68)}$ Asi puede verse en las árulas de la Villa de Maternus, en Carranque (Toledo), y de la Villa de la Ermita de San Bartolomé (Atalaya del Cañavate, Cuenca).

(69) Árula de terracota con lucernas adosadas, hallada en la despensa de la Villa de Vilauba (Camós, Gerona) (Ruiz de Arbulo 1996: 121-122; Figura 15).

(70) Árula hallada en el entorno de las casas n. 1 y n. ${ }^{\circ} 2$ de Emporiae (L'Escala, Gerona) (inédita, agradecemos a los Dres. Xavier Aquilué y Pere Castanyer las facilidades ofrecidas para el estudio in situ de los testimonios de culto doméstico emporitanos). Ara de la Casa de la Plaza de San Ginés, en Cartagena y árula de la Casa en la C/ Lleida n. ${ }^{\circ}$ 27, en Tarragona (Montón 1996: 59, n. ${ }^{\circ 1}$ ).

(71) Algunas de las piezas con estos restos de fuego son una de las árulas de la Plaça del Rei en Barcelona, un árula hallada en la Villa de Casa del Racó (San Juliá de Ramís, Gerona; Burch et al. 1995: 104) y el ara y un árula de la Casa de la Plaza de San Ginés en Cartagena.

(72) Árula de una villa en la C/ Montevideo de Barcelona (Beltrán de Heredia 2001a: 155, n. ${ }^{\circ}$ 78). Árula del Edificio B del Camp de les Lloses (Tona, Barcelona) (Álvarez Arza et al. 2000: 278-279). Árula de la Casa de la C/ Lleida n. ${ }^{\circ} 27$, en Tarragona (Montón 1996: 59, n. $\left.{ }^{\circ} 71\right)$. Dos árulas de la Villa de la Canaleta (Vila-seca, Tarragona) (Adserias 1998: 64-68). 

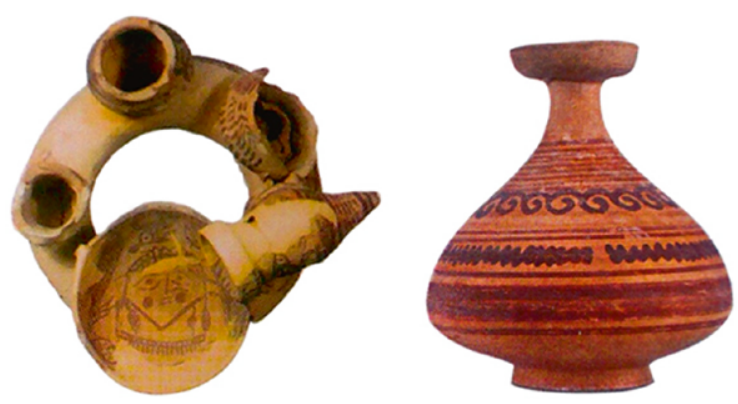

de cultos dispares, lejos de la idea de la imposición de la religión romana sobre el resto de creencias.

Las fórmulas que suelen presentar estas inscripciones son diversas variantes del "votum", por un lado ${ }^{73}$, y la dedicación "sacrum", por otro ${ }^{74}$. El nombre del dedicante suele aparecer en las del primer tipo, para mostrar a la divinidad y a quien la leyese que la persona había cumplido el voto contraído; en las del segundo tipo, la especificación de la persona que consagró el árula no parece relevante, pues no se especifica.

El resto de objetos rituales documentados en las provincias Bética y Tarraconense procede del interior de espacios para el culto y en la mayoría de los casos es dicha procedencia lo que permite identificar su función ritual. Dos de estos contextos no son lararios, sino estancias para el culto de época republicana que responden a tradiciones locales, así como sus materiales.

El grupo más abultado de estos objetos rituales es el de los recipientes asociados a líquidos, como contenedores o para realizar libaciones. En la habitación para el culto de la casa iberorromana del Sector 4-C de Ilici (La Alcudia de Elche, Alicante), fechada entre $228 / 218$ y $42 / 38$ a.C., se haIlaron un kernos y una botellita junto con un thymiaterion de cerámica, evidencias principales de su uso cultual (Figura 17). El kernos (Figura 17a) tiene base tubular y varios recipientes intercomunicados sobre ella, el interior de uno de los cuales está decorado con un rostro femenino engalanado con joyas y con las mejillas arreboladas ${ }^{75}$, que pone sobre la pista del tipo de culto desarrollado en este espacio, probablemente dedicado a la veneración de una diosa madre de la fertilidad (Ramos Fernández 2001-2002: 119-121). Se ha interpretado como un recipiente para libaciones asociado al agua como principio fecundador (ibíd.), pero parece responder también a un tipo de objeto usado en los Kernophoria o fiestas de las primicias celebradas en el Ática y en Sicilia

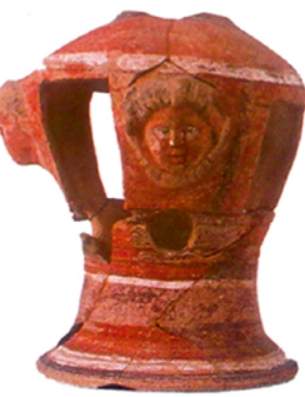

FIgURA 17. Objetos rituales hallados en la habitación D de la Casa del Mosaico Helenístico, en Ilici (La Alcudia de Elche, Alicante). a) Kernos. b) Botellita. c) Thymiaterion. a) AA.VV. 2004: 279; b) ibid.: 279; c) ibíd.: 276. como contenedor de miel, aceite, vino, leche, trigo, etc. (Tortosa 2004: 157). La botellita (Figura 17b), de panza ancha y cuello estrecho, presenta una decoración pintada ibérica de bandas con motivos geométricos intercalados; podría haber sido usada como contenedor del líquido para las libaciones realizadas en el kernos (Ramos Folqués y Ramos Fernández 1976: 21) o como un recipiente para perfumes (Tortosa 2004: 15).

Un jarro con la doble función de almacenamiento y libación de líquidos ha aparecido en la cella vinaria de la Villa de las Musas (Arellano, Navarra), en el entorno del edículo ${ }^{76}$ (Figura 18). Este jarro de cerámica pigmentada tiene una forma peculiar, con tres grandes asas -dos laterales y una posterior- que arrancan del cuello y llegan hasta la panza, y con un pico vertedor, bajo el cual hay un aplique con una pequeña cazoleta, colocada aparentemente para recoger el líquido que gotease, pero que a la vez dificulta el propio vertido (Mezquíriz 2003: 92-93). También en este espacio se ha hallado un anforisco de cerámica (ibid.: 93; Figura 18d), al que la ubicación del larario en la cella vinaria parece otorgarle un significado especial relacionado con la producción del vino; quizá contuvo esta bebida y pudo ser utilizado para libaciones propiciatorias de la actividad productiva, o puede que se trate de un exvoto dedicado a los dioses para favorecer el proceso de elaboración del vino ${ }^{77}$.

El anforisco de la Villa de las Musas recuerda a los microvasos hallados con frecuencia en contextos de culto doméstico ibéricos, razón por la que tienen un alto valor como indicadores para la identificación de estos espacios (Pérez Ruiz 2010, vol.I: 216-221). Precisamente, cuatro de estos microvasos se han documentado en la habitación principal de la Casa $n .{ }^{\circ} 1$ del asentamiento de Mas Castellar de Pontós (Gerona; 225-175 a.C.; Figura 19). Tienen forma de jarrita, cuenco, copa y kantharos y como el espacio en el que se han

${ }^{(73)}$ Ara de la Villa de Gazala (Tardesillas, Soria) y ara de la Villa de San Pedro de Valdanzo (Langa de Duero, Soria), entre otras (Jimeno $1980:$ 46-47, n. 30 y Jimeno et al. 1988-1989: 441-442, respectivamente).

(74) Árula de Uxama Argaela (Burgo de Osma, Soria) dedicada a Júpiter Óptimo Máximo (García Merino 2001: 128-129) y árula de la Casa n. 1 de Clunia (Palol y Vilella 1987: 35, n. $\left.^{\circ} 26\right)$, entre otras.

(75) La decoración de esta pieza responde al estilo I llicitano (Tortosa 2004: 157).

${ }^{(76)}$ Este y otros objetos hallados en la cella vinaria de la Villa de las Musas no proceden exactamente del larario, pero si se subraya su cercanía a este y su posible uso ritual (Mezquíriz 2003: 92-94), con el que coincidimos.

$\left.{ }^{77}\right)$ La relación del larario de la Villa de las Musas con la producción del vino se trata en Pérez Ruiz, e.p.a. 
encontrado, no son de tradición itálica, sino en este caso ibérica y de producción local (Figura 19c). En uno de estos microvasos se han encontrado restos de colorante rojo (Pons 1997: 80), un tipo de pigmento presente con frecuencia en espacios de culto doméstico ibéricos y del área peninsular indoeuropea; otro de los vasitos contenía restos de aceites y resinas olorosas (Pons et al. 1998: 62).

Otro tipo de objeto ritual documentado son las lucernas. Se han hallado cinco: tres procedentes del sacellum de la Villa de Cornelius (L'Énova, Valencia), una del sacrarium de la Villa de Vilauba (Camós, Gerona) y una última de la estancia 3 de la Casa n. ${ }^{\circ} 1$ del poblado ibérico de Mas Castellar de Pontós (Gerona). La forma y la cronología de todas las que han sido identificadas es diferente, siendo la más antigua la de Mas Castellar, una lucerna de aceite de tipo helenístico en cerámica campaniense $A$ con señales de escritura ibérica (Pons 1997: 81; Figura 19d). El fragmento de lucerna del sacrarium de la Villa de Vilauba es de la forma Loeschcke VIII, de cronología postaugustea (Castanyer y Tremoleda 1999: 62); como las figurillas en bronce de este larario, la lucerna estuvo en uso hasta finales del s. III d.C., lo cual demuestra que los objetos que se utilizaban en el ritual doméstico tenían un alto valor simbólico que llevó a sus dueños a conservarlos generación tras generación como reliquias familiares. Finalmente, en el sacellum de la Villa de Cornelius se encontró una lucerna de canal, de probable producción local, similar a la forma Deneauve IXA/Dressel-Lamboglia 5A.5 y con decoración de líneas oblicuas en el disco; junto a ella, otra lucerna de cerámica africana importada, con decoración de hojas de olivo en el mango, y un asa de lucerna con engobe amariIlento (Albiach et al. 2006: 74).

De la habitación para el culto de la Casa del Sector 4-C de Ilici procede, además del kernos y la botellita, un thymiaterion de base acampanada y cuerpo globular, decorado con tres "ventanas" entre las cuales se han aplicado otras tantas máscaras en relieve, bajo cada una de las cuales hay un orificio circular (Figura 17c). Para esta pieza se ha propuesto un origen oriental (Ramos Folqués y Ramos Fernández 1976: 21).

Finalmente, cabe señalar un singular objeto hallado en la estancia principal (3) de la Casa n. ${ }^{\circ} 1$ de Mas Castellar de Pontós, cuyo uso, aunque indefinido, hubo de ser en cualquier caso ritual (Figura 19b). Se trata de una pieza realizada en mármol pentélico, con forma de columna jónica achatada y que parece haber sido rota de forma ritualizada en el momento de abandono del poblado (Pons 1997: 81). Se trata de un objeto de importación, probablemente de un taller ateniense, que debió de llegar a Mas Castellar desde las cercanas Emporion o Rhode (Pons et al. 1998: 60). Estaba colocada junto al gran hogar central de la estancia, como demuestra el hallazgo in situ de la basa.

Este objeto singular guarda un gran parecido con el perirrhanterion encontrado en 1909 en el llamado "Santuario de Asclepio" de Emporion (Pons et al. 1998: 60; Ruiz de Arbulo y Vivó 2008: 82-83), que, sin embargo, está realizado

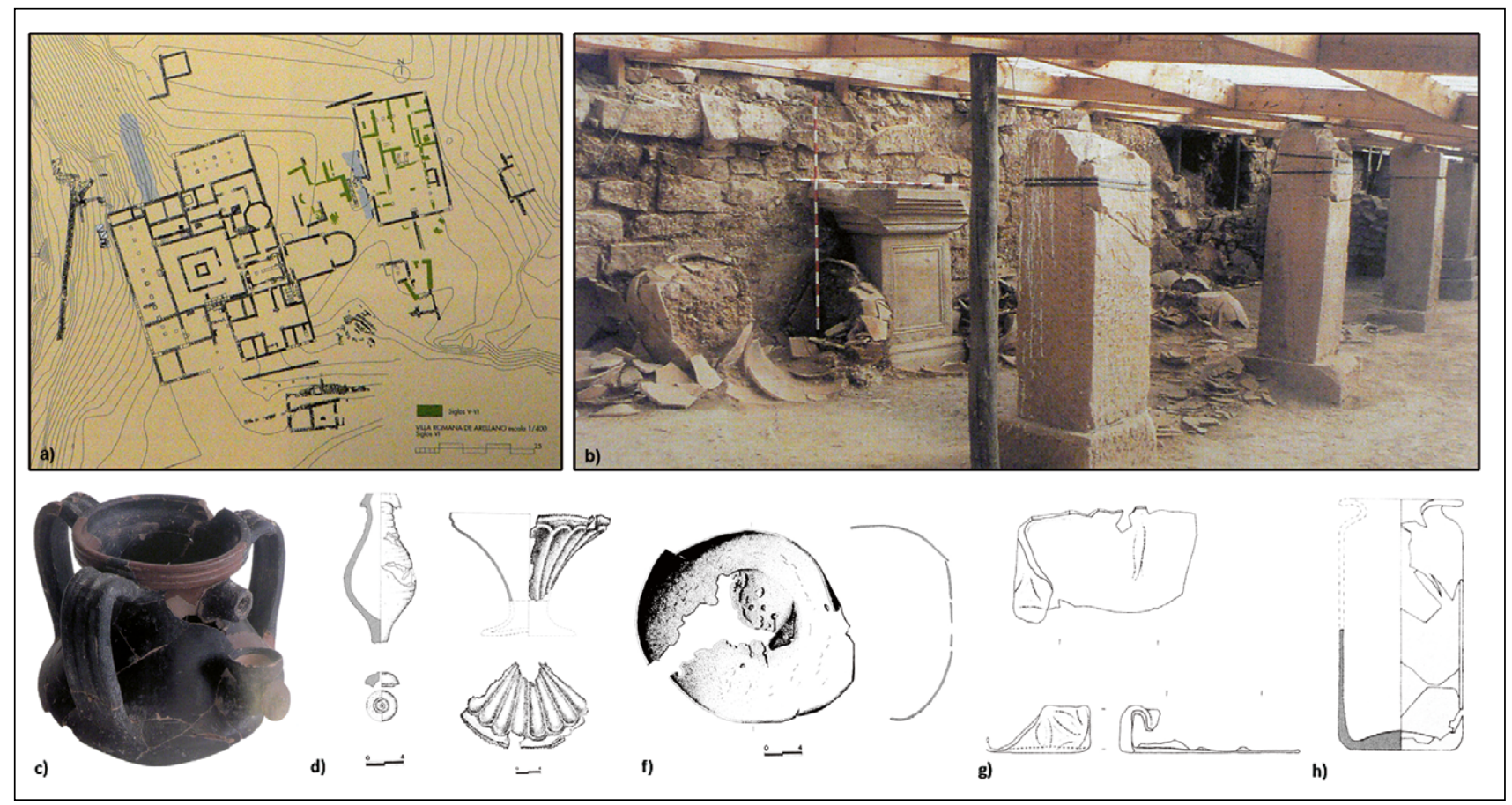

A Figura 18. Larario de la Villa de las Musas (Arellano, Navarra) y materiales asociados. a) Planta de la villa con ubicación del larario. b) Larario en la cella vinaria. c) Jarro ritual de cerámica. d) Anforisco de cerámica. e) Copa gallonada de bronce. f) Colador de bronce. g) Bandeja de vidrio. h) Frasca de vidrio. a) Mezquíriz 2003: 195; b) ibíd.: 129; c) ibíd.: 203; d) ibíd.:97; e) ibíd.: 99; f) ibíd.: 98; g) ibíd.: 99; h) ibíd.: 98. 


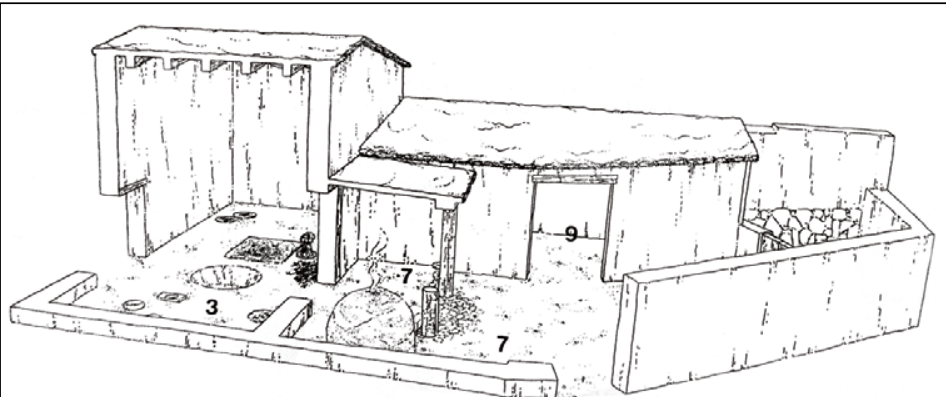

a)



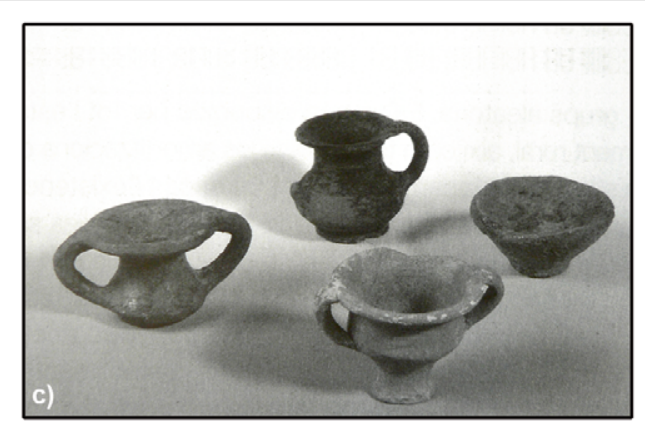

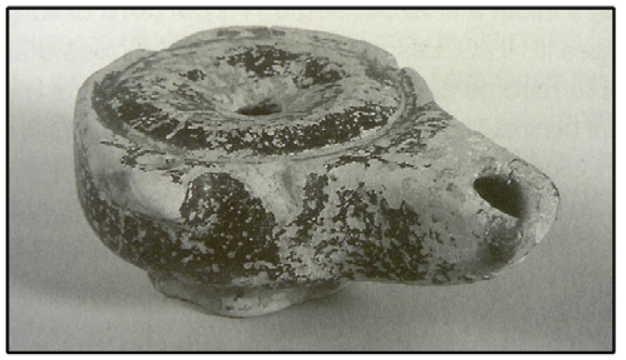

d)

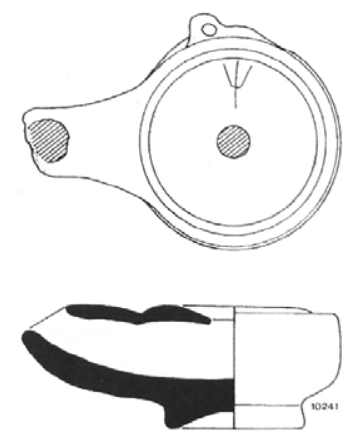

\ Figura 19. Casa $n .^{\circ} 1$ de Mas Castellar de Pontós (Gerona) y materiales asociados al culto hallados en la habitación principal (3). a) Reconstrucción ideal de la casa. b) Pieza de mármol con forma de columna jónica. c) Microvasos cerámicos. d) Lucerna de cerámica con inscripción ibérica. a) Pons 1997: 77, fig. 4; b) Pons et al. 2002: 401, fig. 12.33 (dcha.); Adroher et al. 1993: 44, fig. 9 (izda.); c) Pons et al. 2002: 377, fig. 12.11; d) ibíd.: 381, fig. 12.15 (arriba); Pons 1997: 81, fig. 8 (abajo).

con un material mucho más modesto, piedra caliza local y, por tanto, trabajado en la propia Emporion.

No hay por el momento explicaciones concluyentes sobre la funcionalidad de la pieza de Mas Castellar. Se ha propuesto su uso como ara (Pons et al. 1998: 60); en Grecia, sin embargo, a pesar de haberse hallado altares de mármol pentélico en las casas, ninguno tiene esta forma (Pons 1997: 83), a lo que hay que añadir que el hogar junto al que se encontró la basa ya debía de desempeñar esta función (Pons et al. 1998: 60). Otras opciones propuestas son que se tratara de un monopodium para una mesa de ofrendas o una pila para abluciones, de un pedestal de estatua (ibid.: 61) o de un altar para sacrificios cruentos (Pons et al. 2002: 401). Es también posible que adquiriera un significado nuevo en el contexto ibérico de Mas Castellar de Pontós, sin relación alguna con el uso original para el que fue concebida, de manera que su valor intrínseco como objeto de importación de gran calidad material y formal la habria convertido en una pieza de culto en sí misma (Pons et al. 1998: 61).

\subsection{Instrumentum domesticum y otros materiales hallados en espacios para el culto}

En el entorno del larario de la Villa de las Musas (AreIlano, Navarra) han aparecido fragmentos de varias piezas de vajilla con un posible uso ritual: una copa de bronce de perfil troncocónico invertido y cuerpo gallonado, que podría haber servido para la ingesta ritual de algún tipo de líquido (¿vino?), como complemento de la jarra de cerámica con pico vertedor (vid. sup.); una frasca de vidrio de color verde azulado hallada también en las inmediaciones del larario, y una bandeja de vidrio del mismo color (Mezquíriz 2003: 93-94; Figura 18e, g, h).

También junto al edículo se encontró un cazo colador en bronce (colum), al cual le faltan algunas partes (Figura 18f). Dado que se halló en una cella vinaria, podría haber sido utilizado simplemente para el colado de vino, sin valor ritual alguno (Mezquíriz 2003: 93); pero la cercanía al larario y la asociación a este de objetos que podrían haber servido para 

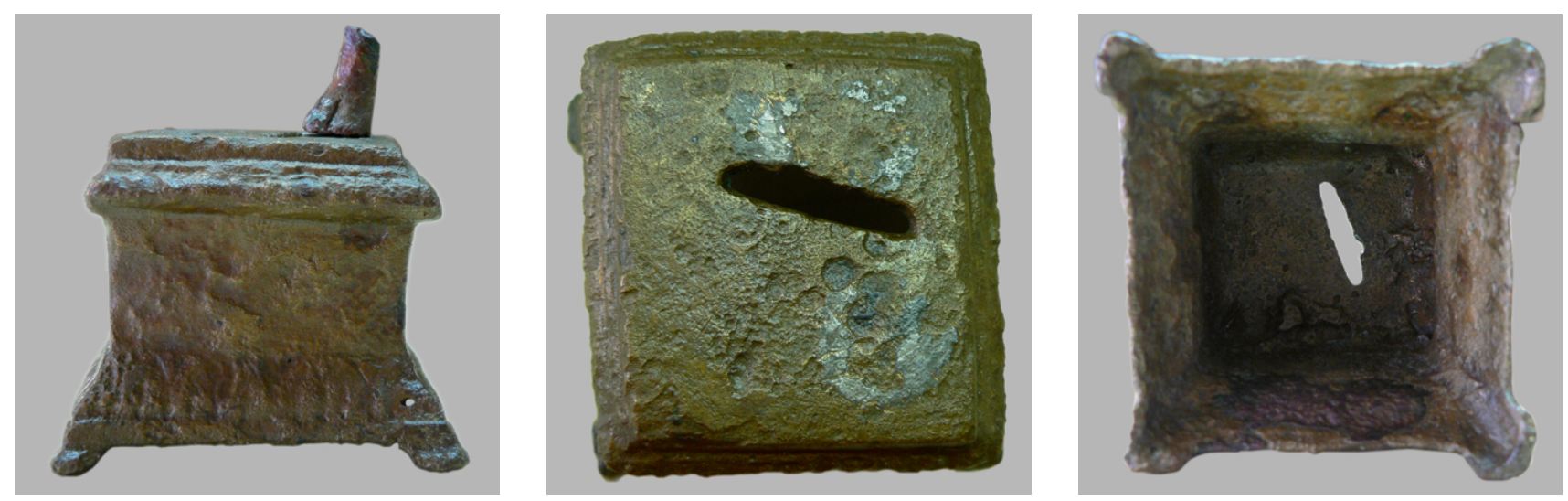

A Figura 20. Pedestal de escultura (probablemente Silvano) con ranura en la parte superior. Procede del larario de la Villa de Vilauba (Camós, Gerona). M. Pérez Ruiz.

contener -jarro, anforisco, frasca- y consumir -copa- vino de forma ritual hace verosímil que el colador fuese utilizado también con funciones litúrgicas.

En la Casa de la Cabeza de Bronce de Pollentia se encontraron, junto a la cabecita de Dióniso/Baco, un aplique en bronce con forma de rostro de sileno y un oinochoe de bronce (Arribas et al. 1973: 86-90), nuevamente un recipiente para contener y verter líquidos, como los diversos objetos rituales antes mencionados. Asociados a estas piezas de bronce había fragmentos cerámicos de platos, vasos, vasitos, ánforas y un ungüentario (ibíd.).

En el sacrarium de la Villa de Vilauba (Camós, Gerona) se han hallado un asa de mueble y un pomo de puerta, ambos en bronce (Figura 11d, e). El pomo perteneció seguramente a la puerta del sacrarium, mientras que el asa, de pequeñas dimensiones, debió de ser parte de un mueble de madera del que no se ha conservado resto alguno (Castanyer y Tremoleda 1999: 61-62).

Hallazgo destacado son las monedas aparecidas en el mismo larario de Vilauba y en el de la Villa de Cornelius (L'Énova, Valencia), pues, como ya se ha visto anteriormente, son relativamente frecuentes en contextos de culto doméstico. En la Villa de Cornelius, las cinco monedas tienen una cronología similar, en torno a mediados del s. IV d.C., es decir, poco antes de la amortización del larario (Albiach y Madaria 2006: 121; Figura 12e). En la Villa de Vilauba, en cambio, las cuatro de las seis monedas (cinco ases y un sestercio) para las que se conoce la cronología fueron acuñadas entre la época augustea y el primer tercio del s. III d.C., abarcando, por tanto, todo el período de uso del larario y siendo la más antigua incluso anterior a este (Castanyer y Tremoleda 1999: 330; Figura 11f). Teniendo en cuenta el cuidado que se puso en la conservación de las piezas del larario de Vilauba, como se ha dicho al hablar de las esculturas y de la lucerna, no sería de extrañar que estas monedas se hubieran ido atesorando también durante el período de uso del sacrarium.

Estos hallazgos nos vuelven a poner sobre la pista de un rito celebrado en el larario en el que se realizaban ofrendas pecuniarias, idea reforzada por el hecho de que el pedestal de la escultura interpretada como Silvano, en Vilauba, presenta una ranura estrecha y alargada en la cara superior (Figura 20), como otras piezas estudiadas por A. KaufmannHeinimann (1998: 168-180; vid. sup.) e interpretadas como huchitas $^{78}$. En el caso de Vilauba cabe preguntarse si las ofrendas estaban directamente relacionadas con Silvano, en cuyo pedestal estaba la ranura para introducir las monedas, o si, a pesar de esto, estaban dedicadas a todos los dioses del larario. Resulta curioso también que no fuera el pedestal de Mercurio el usado como hucha, ya que sus esculturas son las más utilizadas para este fin $^{79}$, si bien tampoco en la Villa de Cornelius las monedas tienen relación con Mercurio, pues la única divinidad documentada es Hércules.

\section{CONCLUSIONES}

Los materiales que encontramos asociados a espacios de culto doméstico en el mundo romano presentan, en función de lo visto hasta aqui, una alta variedad tipológica y funcional, que no permite definir un ajuar o ajuares específicos para la celebración de los ritos que tenían lugar en el larario, seguramente porque existieron variaciones en estos mismos ritos en función de cada familia, de cada región y de la propia evolución del culto a lo largo del tiempo.

Existen, sin embargo, recurrencias significativas en este registro material, que aportan valiosa información sobre la actividad ritual doméstica, pues muestran que las divinidades

${ }^{(78)}$ Muchas de estas "huchas", sin embargo, carecen de cierre en la parte inferior, como la de Vilauba, por lo que o bien tenían un tapón realizado en un material perecedero, o bien las monedas caian por la ranura a un platillo o directamente a la superficie de apoyo de la escultura (Kaufmann-Heinimann 1998: 176).

${ }^{(79)}$ Véase la relación de Mercurio con las huchas domésticas en Kaufmann-Heinimann 2011: 197. 
veneradas estaban presentes a través normalmente de imágenes de culto, cuyo alto valor simbólico queda demostrado en el prolongado uso de algunas de ellas; que se realizaban sacrificios incruentos sobre árulas portátiles; que el fuego solía estar presente, bien en estas árulas, bien en otros objetos rituales como quemaperfumes; que era frecuente el uso de algún tipo del líquido (agua, vino...) que se almacenaba, vertía y bebía en jarros, vasos, copas, etc.; que solía haber una fuente de luz, normalmente gracias a la presencia de lucernas, o que era común la realización de ofrendas pecuniarias.

La asociación de los materiales a los espacios de culto de los que proceden y su estudio conjunto resultan fundamentales para obtener un conocimiento lo más completo posible del culto doméstico en época romana. Sin los materiales, que en muchos casos no se han conservado o no están adecuadamente asociados a sus contextos, las capillas domésticas se vacian en gran parte de significado, pues se pierde la información relativa al ritual al que estaban destinadas y a las divinidades a las que estaban dedicadas ${ }^{80}$.

Esta necesidad de estudiar conjunta y sistemáticamente la arquitectura doméstica de época romana con los materiales que aparecen en cada espacio para definir adecuadamente su uso viene siendo subrayada desde hace años por Penelope M. Allison (1992; 2001; 2004; 2010, entre otros). Aunque actualmente esto esté fuera de discusión y resulte incluso una obviedad, no lo ha sido durante mucho tiempo en la práctica arqueológica, como demuestra la extensísima bibliografía sobre Pompeya, ciudad paradigmática para cualquier estudio sobre este tema.

En este sentido, el análisis de los materiales asociados al culto doméstico realizado en el primer apartado, basado principalmente en las evidencias pompeyanas, demuestra que aún queda trabajo por hacer, a partir del cotejo de datos de antiguas excavaciones, y seguramente los resultados arrojarán luz sobre interesantes cuestiones como la funcionalidad de los lararios, objeto de especial atención últimamente pero que se apoya por el momento en otros datos, como la ubicación en la casa, la decoración, las características arquitectónicas..., y menos en los materiales involucrados en el rito.

En Hispania, uno de los principales problemas en la identificación de espacios para el culto doméstico es precisamente la falta de información sobre materiales asociados. Es también una de las principales ayudas en los casos en los que se cuenta con esta información, ya que permite conocer las divinidades a las que estaban dedicados dichos espacios, como Hércules en el caso de la Villa de Cornelius (L'Énova, Valencia) o el Lar, Mercurio, Fortuna y Silvano en el de la Villa de Vilauba (Camós, Gerona); la existencia de ritos constatados en otras zonas del mundo romano, como la realización de ofrendas pecuniarias en las mismas villas, posibles libaciones en la Villa de las Musas (Arellano, Navarra) o sacrificios con fuego en altares portátiles como los de la Casa de la Plaza de San Ginés (Cartagena, Murcia); o bien el mantenimientos de capillas destinadas a la veneración de divinidades indígenas al menos hasta el cambio de Era, como en la Casa del Sector 4-C de Ilici (La Alcudia de Elche, Alicante).

Se da también el caso en Hispania, como se ha visto, de que aras e imágenes de culto aparezcan en casas en las que no hay evidencia de una capilla, de manera que es su presencia la que marca la existencia de una actividad ritual, especialmente en el caso de las aras, señalizadores de dicha actividad en el lugar en el que se encuentran, bien sea de forma permanente o temporal. Estos elementos forman parte de lo que Maddalena Bassani (2005: 74; 2008: 9) ha denominado "indicadores de culto", pues marcan con cierto grado de seguridad algún tipo de actividad doméstica de culto o incluso la existencia de un espacio destinado a ella ${ }^{81}$.

A diferencia de las imágenes de culto y de las árulas, la mayoría de los objetos rituales o de otro tipo hallados en lararios solo pueden relacionarse con ellos cuando se encuentran dentro o junto a ellos, por lo que carecen de valor como "indicadores de sacralidad". Como hemos dicho, la disparidad de estos objetos es tan alta que, ni a partir de los testimonios hispanos, ni a partir de los procedentes de otras zonas del mundo romano, es posible establecer una tipología que permita suponer que el hallazgo de una pieza con una forma o un uso determinado fuese un posible objeto ritual.

Por otro lado, el análisis en Hispania de un grupo de estructuras y materiales que abarcan un amplio período cronológico, desde el s. II a.C. hasta el s. V d.C., permite apreciar que los espacios para el culto con materiales de tradición indígena -exclusivamente o en convivencia con otros itálicos- no se documentan más allá del cambio de Era, siendo los más tardios los de la Casa del Sector 4-C de Ilici. Desde ese momento, tanto los espacios como los materiales dentro de ellos responden a la tradición itálica ${ }^{82}$.

Los materiales asociados al culto doméstico son, por tanto, piezas fundamentales para el conocimiento y la mejor comprensión de este, que, sin embargo, creemos que no siempre han recibido la atención que merecen. Queda por hacer la interesante labor de cotejarlos con las fuentes textuales para poder definir mejor los ritos que las familias realizaban en sus capillas domésticas. •

${ }^{80}$ Esto último en menor medida, gracias a que las imágenes de culto son el grupo de objetos que tradicionalmente más ha atraído la atención de los investigadores.

${ }^{(81)}$ Esto no significa, sin embargo, que este tipo de objetos, árulas anepigráficas y esculturas en bronce de pequeño formato especialmente, deban ser interpretadas como elementos de culto doméstico aún cuando se desconoce su procedencia, pues se han encontrado también en otros contextos (santuarios, tumbas...), de modo que el uso doméstico es solo uno de los posibles.

${ }^{82}$ Si se dan, en cambio, otras manifestaciones de culto doméstico de tipo indígena que conviven con los lararios, como enterramientos infantiles y depósitos votivos, que duran al menos hasta el s. II d. C. Sobre este particular véase Pérez Ruiz, e.p.b. 


\section{BIBLIOGRAFÍA ${ }^{83}$}

AA.W. 2004: Iberia, Hispania, Spania. Una mirada desde llici. Alicante. Abascal Palazón, J. M. 1998: "Inscripciones votivas de Osa de la Vega (Cuenca, Hispania Citerior)". Saguntum 31: 259-262.

- 2000: "Segóbriga y la religión en la Meseta sur durante el Principado". Iberia 3: 25-34.

Abascal Palazón, J. M. y Alföldy, G. 1998: "Zeus Theos Megistos en Segobriga". AEspA 71: 157-168.

AdAmo Muscettola, S. 1984: "Osservazioni sulla composizione dei larari con statuette in bronzo di Pompei ed Ercolano". En U. Gehrig (ed.): Toreutik und figürliche Bronzen römischer Zeit (Berlin, 13-17 mayo 1980). Berlin: 9-32.

Adroher, A. M. a, Pons y Brun, E. y RUIz de Arbulo, J. 1993: "El yacimiento de Mas Castellar de Pontós y el comercio del cereal ibérico en la zona de Emporion y Rhode (ss. IV-II a.C.)". AEspA 66: 31-70.

AdSERIAS SAnS, M. 1998: Evidències del passat. Prehistòria i món antic a Vila-seca. Tarragona.

Albiach Descals, R., Gallego, A. y Garcia-Prosper, E. 2006: "Las reformas en la villa". En R. Albiach Descals y J. L. de Madaria: La villa de Cornelius (L'Ėnova, Valencia). Valencia: 70-85.

ALBIACH DESCALS, R. y MADARIA, J. L. DE 2006: La villa de Cornelius (L'Énova, Valencia). Valencia.

Aluson, P. M. 1992: "Artefact Assemblages: not "the Pompeii Premise". En E. Herring, R. Whitehouse y J. Wilkins (eds.): Papers of the Fourth Conference of Italian Archaeology 3. New developments in Italian archaeology 1. London: 49-56.

- 2001: "Using the material and written sources: turn of the Millenium approaches to Roman domestic space". AJA 105.2: 181-208.

- 2004: Pompeian Household. An analysis of the material culture, Los Angeles.

- 2006: The Insula of the Menander at Pompeii, vol. III. The finds, a contextual study. Oxford.

- 2010: "Understanding Pompeian households practices through their material culture". Facta 3: 11-33.

Álvarez Arza, R., Duran I Caixal, M., Mestres Santacreu, I., Molas Font, M. a D. y Principal PonCE, J. 2000: "El jaciment del Camp de les Lloses (Tona, Osona), i el seu taller de metalls". En C. Mata Parreño y G. Pérez Jordà (eds.): III Reunió sobre economía en el Món Ibèric. Saguntum extra 3. Valencia: 271-281.

ArRiBas, A., TarRadelL, M. y Woods, D. 1973: Pollentia I. Excavaciones en Sa Portella, Alcudia (Mallorca). Madrid.

BAKKER, J. T. 1994: Living and working with the gods. Studies of evidence for private religion and its material environment in the city of Ostia (100-500 a.D.). Amsterdam.

BARATA, G. 2001: Il culto di Mercurio nella Penisola lberica. Barcelona.

BASSANI, M. 2005: "Ambienti e edifici di culto domestici nella Penisola Iberica". Pyrenae 36.1: 71-116.

- 2008: Sacraria. Ambienti e piccoli edifici per il culto domestico in area vesuviana. Roma.

Beltrán de Heredia Bercero, J. (dir.) 2001: De Barcino a Barcinona (siglos I-VIII. Los restos arqueológicos de la plaza del Rey del Barcelona. Barcelona.

Beltrán LloRis, M. 1998: "Museo de Zaragoza. Colonia Celsa. Catálogo Monográfico". BMusZaragoza 14: 5-172.

Beltrán Lloris, M. y Paz Peralta, J. A. (Coords.) 2003: Museo de Zaragoza. Guía. Zaragoza.

BÖMER, F. 1943: Ahnenkult und Ahnenglaube im alten Rom. Beihefte zum Archiv für Religionswissenschaft 1. Leipzig-Berlin.

Bonet Rosado, H. 1995: El Tossal de San Miquel de Llíria. La antigua Edeta y su territorio. Valencia.
BoniNI, P. 2011: "Le tracce del sacro. Presenze della religiosità privata nella Grecia romana". En M. Bassani y F. Ghedini (eds.): Religionem significare. Aspetti storico-religiosi, strutturali, iconografice e materiali dei sacra privata. Atti del incontro di studi (Padua, 8-9 junio 2009). Roma: 205-227.

BOUCHER, S. y OgGIANO-BITAR, H. 1995: "Les Lares des Provinces romaines: essai de datation", en S. T. A. M. Mols, A. M. Gerhartl-Witteveen, H. Kars, W. J. Th. Peters y W. J. H. Willems (eds.): Acta of the 12th International Congress on Ancient Bronzes (Nijmegen, 1992). Amersfoort: 231-240.

BoYCE, G. K. 1937: Corpus of the Lararia of Pompeii. Roma.

BULARD, M. 1923: "Sur une peinture d'autel découverte a Dèlos en 1912 et représentant un dieu chèvrepied". $B C H$ 47: 455-487.

Burch, J., Carrascal, C., Merino, J. y Navarro, N. 1995: "La Casa del Racó: un establiment rural d'època romana a Sant Julià de Ramis", en B. Agusti, J. Burch, y J. Merino (eds.): Excavacions d'urgència a Sant Julià de Ramis. Anys 1991-1993. Girona: 95-107.

CASTANYER MASOLIVER, P. y TREMOLEDA I TRILLA, J. 1997: "La villa romana de Vilauba, Banyoles (provincia de Girona). Excavación de un ámbito de culto doméstico". MM 38: 163-175.

- 1999: La vil.la romana de Vilauba. Un exemple de l'ocupació i explotació del territori a la comarca del Pla de l'Estany. Girona.

CHARLES-LAFORGE, M-0. 2007: "Imagines maiorum" et portraits d'ancêtres à Pompei". En AA.W.: Contributi di Archeologia Vesuviana III. Roma: 158-171.

COMES, R. y RodÁ DE LLANZA, I. (EDS.) 2002: Scripta manent, la memoria escrita de los romanos. Murcia.

CoralinI, A. 2001: Hercules domesticus. Immagini di Ercole nelle case della regione vesuviana (I secolo a.C.-79 d.C.). Napoli.

CORELL, J. 2002: Inscripcions romanes del País Valencià I. Saguntum y el seu territori. Valencia.

- 2006: Inscripcions romanes del País Valencià III. Saetabis i el seu territori. Valencia.

D'Ambrosio, A. y Borriello, M. 2001: Arule e bruciaprofumi fittili da Pompei. Napoli.

De MARCHI, A. 1896 (2003): II culto privato di Roma Antica, vol. I. La religione nella vita domestica. Iscrizioni e offerte votive. Forli.

Deonna, W. y Renard, M. 1961: Croyances et superstitions de table dans la Rome Antique. Bruxelles.

DI CAPUA, F. 1950: "Sacrari pompeiani". En AA.W.: Pompeiana. Raccolta di studi per il secondo centenario degli scavi di Pompei. Napoli: 6085.

DORCEY, P. F. 1992: The cult of Silvanus. A Study in Roman Folk Religion. Leiden-New York-Köln.

EBnÖTHeR, C. y KaUfMANn-Heinimann, A. 1996: "Ein Schrank mit Lararium des 3. Jahrhunderts". En V. Schaltenbrand-Obrecht y C. Ebnöther (eds.): Beiträge zum römischen Oberwinterthur-VITUDURUM 7. Ausgrbungen in Unteren Bühl. Die Funde aus Metall. Eis Schrank mit Lararium des 3. Jahrhunderts. Zürich-Egg: 229-251.

EliA, 0. 1962: "Culti familiari e privati della Campania. Arule fittili pompeiane". En M. Renard (ed.): Hommages á Albert Grenier, vol. 2. Bruxelles: $559-566$.

FLOWER, H. 1996: Ancestor Masks and Aristocratic Power in Roman Culture. Oxford.

FRÖHLICH, T. 1991: Lararien- und Fassadenbilder in den Vesuvstädted. Untersuchungen zur "volkstümlichen" pompejanischen Malerei. Mainz.

GAMER, G. 1989: Formen römische Altäre aufder hispanischen Halbinsel. Mainz.

García y Belido, A. 1949: Esculturas romanas de España y Portugal. Madrid. 
García Merino, C. 2001: "Novedades de epigrafía votiva en el valle oriental del Duero: un documento de culto doméstico a Júpiter Conservador, otra vez la diosa Degante... de los Argaelos y aras de Uxama". BSAA 67: 125-140.

GimENO PASCUAL, H. 2009: "Epigrafía y "epigraphic habit" en Valeria, una ciudad de la zona nororiental del conventus Carthaginensis". En E. Gonzalbes Cravioto (coord.): La ciudad romana de Valeria (Cuenca). Cuenca: 157-184.

GoRINI, G. 2011: "L'offerta della moneta agli dei: forma di religiosità privata nel mondo antico". En M. Bassani y F. Ghedini (eds.): Religionem significare. Aspetti storico-religiosi, strutturali, iconografice e materiali dei sacra privata. Atti del incontro di studi (Padua, 8-9 junio 2009). Roma: 247-256.

GugLIELMI, S. 2007A: "Estatua de Isis-Fortuna". En AA.W.: Roma S.P.Q.R Madrid: 248-249.

- 2007b: "Herma de Hércules". En AA.W.: Roma S.P.Q.R. Madrid: 252253.

GuidobaldI, M. ${ }^{a}$ P. 2003: "La bottega di un gemarius (Ins. Or. II, 10) e l'ingannevole "stanza della ricamatrice". En A. D'Ambrosio, P. G. Guzzo y M. Mastroroberto (eds.): Storie da un'eruzione. Pompei, Ercolano, Oplontis. Milano: 102-111.

Guiral Pelegrin, C. y Martin Bueno, M. 1996: Bilbilis I. Decoración pictórica y estucos ornamentales. Zaragoza.

Gurt Esparraguera, J. M.a 1985: "Los materiales arqueológicos de Puypullin (Loarre, Huesca)". Bolskan 2: 153-166.

JASHEMSKI, W. 1979: The Gardens of Pompeii, Herculaneum and the Villas Destroyed by Vesubius. New Rochelle-New York.

Jimeno Martinez, A. 1980: Epigrafía romana de la Provincia de Soria. Soria.

Jimeno Martínez, A., Argente Oliver, J. L. y Gómez Santa Cruz, J. 19881989: "La "villa" de San Pedro de Valdanzo (Soria)". Zephyrus 41-42: 419-454.

JoLY, M. 2007: "Luxe et ordinaire dans les sanctuaires: I'exemple des offrandes" En F. Baratte, M. Joly y J.-C. Béal (dirs.): Autour du trésor de Mâcon. Luxe et quotidien en Gaule romaine. Saint-Just-la-Pendue: 105-121.

Kaufmann-Heinimann, A. 1998: Götter und Lararien aus Augusta Raurica. Herstellung, Fundzusammenhänge und sakrale Funktion figürlicher Bronzen in einer römischen Stadt. Augst.

- 2007a: "Statuettes de laraire et religión domestique à Pompéi", en AA.W., Contributi di Archeologia Vesuviana III. Roma: 151-157.

- 2007b: "Les statuettes de Mâcon, un ensemble particulier". En F. Baratte, M. Joly y J.-C. Béal (dirs.): Autour du trésor de Mâcon. Luxe et quotidien en Gaule romaine. Saint-Just-la-Pendue: 19-38.

- 2011: "Religion in the house". En J. Rüpke (ed.): A companion to Roman religion. Malden-0xford-Chichester: 188-201.

KoppeL, E. M. 1993: "La escultura en el entorno de Tarraco: las Villae". En T. Nogales Basarrate (coor.), Actas de la I Reunión sobre escultura romana en Hispania. Madrid.

KUnCKEL, H. 1974: Der römische Genius. Heidelberg.

MAIURI, A. 1932: La casa del Menandro e il suo tesoro di argenteria. Roma.

Martín-Bueno, M. 1975-1976: "Elementos de cultos orientalizantes en Bilbilis (Calatayud)". Caesaraugusta 39-40: 165-174.

- 1979: "Nuevos materiales epigráficos zaragozanos". Caesaraugusta 47-48: 297-305.

Martin Camino, M. y Roldán Bernal, B. 1997: "Plaza de San Ginés número 1 esquina calle del Duque". Memorias de Arqueología. Excavaciones arqueológicas en Cartagena 1982-1988. Murcia: 126-128.

Martinez Munilla, M. 1951: "Sobre un ara romana de Itálica". AEspA 24: $208-210$

Martinez Rodriguez, A. 1991-1992: "El Villar de Coy. Una villa romana de larga continuidad". AnMurcia 7-8: 207-217.

Mesado Oliver, N. 1971: "Estatua femenina y Mercurio del Museo de Burriana (Castellón)". AEspA 44: 169-171.

Mezouiriz IRUjo, M. ${ }^{\text {A }}$. 2003: La villa romana de Arellano. Navarra.
Montón Brotó, F. J. 1996: Las arulas de Tárraco. Tarragona.

Moreno Pérez, A. S., Orfila Pons, M., Chávez, M. a E. y Cau, M. A. 2011: "Las áreas residenciales de Pollentia (Alcudia, Mallorca) y sus materiales figurados en soportes plásticos". En T. Nogales Basarrate e I. Rodà de Llanza (eds.): XI Coloquio Internacional de Arte Romano Provincial "Roma y las Provincias: Modelo y Difusión" (Mérida, 18-22 mayo 2009). Mérida: 927-935.

Palol Salellas, P. de y Vilella, J. 1987: Clunia II. La epigrafía de Clunia. Madrid.

PERA, R. 1993: "La moneta antica come talismano". RItNum 95: 347-361.

Pérez Ruiz, M. 2008: "Un caso singular de estatua romana de culto doméstico". AEspA 81: 273-287.

- 2010: El culto doméstico en la Hispania romana. Provincias Baetica y Tarraconensis. Tesis doctoral. Universidad Autónoma de Madrid.

- 2011a: "El culto en la casa romana". AnMurcia 23-24 (2007-2008): 199-229.

- 2011b: "Serpiente". Despalabro 5: B93-B96.

- e.p.c., 2013: "Topografia del culto en las casas romanas de la Baetica y la Tarraconensis". MM 54.

- e.p.b., 2013: "Domestic cult and ethnicity. Surveying local identity and cultural interactions throught private religion in the Roman provinces Baetica and Tarraconensis". En L. Banbardieri, A. d'Agostino, G. Guarducci, V. Orsi y S. Valentini (eds.): Identity and connectivity. Proceedings of the 16th Symsosium on Mediterranean Archaeology (Florence, 1-3 March 2012), 0xford.

PeRnICE, E. 1932: Hellenistische Tische, Zisternenmündungen, beckenuntersätze Altäre und Truhen. Berlin-Leipzig.

Pons I BRUn, E. 1997: "Estructures, objectes y fets cultuals en el jaciment protohistòric de Mas Castellar (Pontós, Girona)". QuadCast 18. Espacios y lugares cultuales en el mundo ibérico: 71-89.

Pons I Brun, E., Ruiz de Arbulo, J. y Vivó, D. 1998: "El yacimiento ibérico de Mas Castellar de Pontós (Girona). Análisis de algunas piezas significativas". En C. Aranegui Gascó, (coord. cient.): Los Iberos. Príncipes de Occidente. Estructuras de poder en la sociedad ibérica (Barcelona, 12-14 marzo 1998). Barcelona: 55-64.

Pons I Brun, E. (dir.) et al. 2002: Mas Castellar de Pontós (Alt Empordà). Un complex arqueològic d'època ibérica (excavacions 1990-1998). Girona.

POUTHIER, P. y RouILlaRd, P. 1986: "Faunus ou l'iconographie impossible". En L. Kahl, Ch. Augé y P. Linant de Bellefonds (dirs.): Iconographie Classique et identités regionales (Paris, 26-27 mayo 1983). Paris: 105-109.

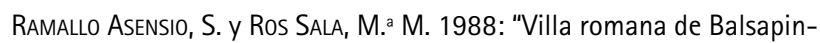
tada (Valladolises, Murcia)". AnMurcia 4: 155-168.

Ramos FernÁndez, R. 2001-2002: "Áreas de culto en La Alcudia ibérica". AnMurcia 16-17. Studia E. Cuadrado: 117-126.

Ramos Foloués, A. y Ramos Fernández, R. 1976: Excavaciones en La Alcudia de Elche durante los años (1968 al 1973). Madrid.

RıcciomI, D. 1978: Terrecotte votive dell'Antiquarium Comunale di Roma. 1. Arule. Roma.

Rodriguez García, P. 1999: "Cultos domésticos en la Galicia romana". En R. Balbin Behrmann y P. Bueno Ramírez (eds.): // Congreso de Arqueología Peninsular. Vol 4 (Zamora, 24-27 septiembre 1996). Zamora: 147-151.

Ruiz de ARbulo, J. 1994: "Los cernos Figurados con cabeza de Core. Nuevas propuestas en torno a su denominación, función y origen". Saguntum 27: 155-171.

- 1996: "Altares domésticos y ritos orientales. Las árulas con lucernas adosadas". Cypsela 11: 117-124.

Ruiz de Arbulo, J. y Vivó, D. 2008: "Serapis, Isis y los dioses acompañantes en Emporion: una nueva interpretación para el conjunto de esculturas aparecido en el supuesto Asklepieion emporitano". RAPon 18: 71-140.

SAMTER, E. 1901: Familienfesten der Griecher und Römer. Berlin.

SANTROT, J. 2007: "Lares et laraires en Gaule romaine. Chapelles luxueuses et oratoires populaires". En F. Baratte, M. Joly y J.-C. Béal (dirs.): 
Autour du trésor de Mâcon. Luxe et quotidien en Gaule romaine. Saint-Just-la-Pendue: 75-104.

StIRLING, L. M. 2008: "Pagan statuettes in Late Antique Corinth: Sculpture from the Panayia Domus". Hesperia 77.1: 89-161.

TORTOSA Rocamora, T. 2004: "Tipología e iconografía de la cerámica ibérica Figurada en el enclave de La Alcudia (Elche, Alicante)". En T. Tortosa Rocamora (ed.): El yacimiento de
La Alcudia: pasado y presente de un enclave ibérico. Madrid: 71-222.

ToYnBeE, J. M. C. 1971: Death and Burial in the Roman World. Ithaca. VARONe, A. 2002: "Die Villa dei Misteri". En F. Coarelli (ed.): Pompeji. München: 346-359.

VentuRa Solsona, S. 1942: "Museo Arqueológico de Tarragona". MMAP 1941: 128-139. 